\title{
Phenomenology of Sahelian convection observed in Niamey during the early monsoon
}

\author{
C. Dione ${ }^{\mathrm{a}, \mathrm{b} *}, \mathrm{M}$. Lothon ${ }^{\mathrm{b}}$, D. Badiane ${ }^{\mathrm{a}}$, B. Campistron ${ }^{\mathrm{b}}$, \\ F. Couvreux ${ }^{\mathrm{c}}$, F. Guichard ${ }^{\mathrm{c}}$ and S. M. Sall ${ }^{\mathrm{a}}$ \\ ${ }^{a}$ Université Cheikh Anta Diop, ESP, LPAO-SF, Dakar, Sénégal \\ ${ }^{\mathrm{b}}$ Laboratoire d'Aérologie, UMR 5560 CNRS, Université Paul Sabatier, Toulouse, France \\ ${ }^{c}$ CNRM-GAME, UMR 3589, CNRS, Météo-France, Toulouse, France \\ ${ }^{*}$ Correspondence to: C. Dione, Centre de Recherches Atmosphériques, 8 route de Lannemezan, \\ 65300 Campistrous, France. E-mail: dione0109@yahoo.fr
}

This study aims to achieve a better understanding of the initiation of deep convection in the Sahel by using the African Monsoon Multidisciplinary Analyses (AMMA) dataset. Based on the Massachusetts Institute of Technology (MIT) radar, wind profiler, satellite data, surface flux and meteorological stations, we have characterised the atmospheric convection which occurred over Niamey during the onset period of the monsoon. From 6 to 31 July, radar reflectivity fields combined with brightness temperatures were used to classify the type of convection observed each day within a $50 \mathrm{~km}$ radius of the MIT radar location. Four types of convection have been identified: fair weather (FW) with a clear sky throughout the entire day, shallow convection (SH), afternoon locally initiated deep convection (LC), and propagating deep convection (PC). Subsequently, the mechanisms responsible for the initiation of local deep convection were investigated.

Neither early morning convective available potential energy nor the convective triggering potential allowed the onset of local deep convection to be predicted correctly. In effect, they were both favourable to deep convection most of the time, while convective inhibition was typically quite large. Our results show that the daytime growth of the atmospheric boundary layer needed to be sufficient for local deep convection to occur during that period. Convergence lines, which grew within the morning clear-air roll organisation, were found to be precursors of local deep convection. Classes FW, SH and LC ultimately behaved quite similarly, with notable convergence in the lower troposphere, but FW showed smaller boundarylayer growth, and FW and SH classes revealed a significant divergence above the boundary layer. Most cases of LC generated a circular gust front. These density currents almost always generated new convective cells.

Key Words: Sahel; atmospheric boundary layer; shallow/deep convection transition; convection initiation 


\section{Introduction}

In the Sahel, rainfall is most commonly associated with Mesoscale Convective Systems (MCSs) (Le Barbé and Lebel, 1997; D'Amato and Lebel, 1998) and squall lines. In the past, many factors which modulate MCS activity have been identified, namely moisture convergence in the lower troposphere, African Easterly Waves (AEWs) and the African Easterly Jet (AEJ). Deep convection in West Africa is often associated with AEWs (Thorncroft, 1995). However, in West Africa, particularly in the Sahel, many storms observed during the summer cannot be related to large-scale dynamic processes such as AEWs. Such storms are smaller than the typical MCS, but still make a significant contribution to the transport of moisture and dust, due to their large number.

The triggering of deep convection also depends on the surface heat flux and soil moisture (Findell and Eltahir, 2003; Taylor and Ellis, 2006). Bart et al. (2010) demonstrated a seasonal variation of the level of condensation and the Convective Triggering Potential (CTP) and high sensitivity of the CTP and Humidity Index (HI) anomalies to soil moisture using a regional climate model in West Africa. Deep convection is sensitive to soil moisture and temperature heterogeneities (Taylor and Lebel, 1998; Taylor et al., 2003; Comer et al., 2007; Taylor et al., 2011). Garcia-Carreras et al. (2011) showed that the convergence zone created by heterogeneities between crop and forest provided optimum conditions for the initiation of convection in the afternoon. For the American Great Plains, Fabry (2005) illustrated that the location of convection initiation at synoptic scales and at the upper end of mesoscales was most sensitive to variability in temperature. However, at smaller scales, storm development becomes extremely sensitive to the strength of updraughts. Weckwerth and Parsons (2006) provided a summary of convective storm initiation and evolution based on the results of the 2002 International $\mathrm{H} 2 \mathrm{O}$ Project (IHOP; Weckwerth et al., 2004), including frontal zones, gust fronts, boundary-layer rolls, drylines, bores and land surface effect. Wilson et al. (1992) showed that the intersection of convective horizontal rolls and convergence lines can initiate the formation of strong thunderstorms. Zhang and Klein (2010) found a good correlation between higher relative humidity above the boundary layer and the earlier onset and longer duration of afternoon precipitation events.

Conditions for convection initiation have been analyzed in the Southern Great Plains (Zhang and Klein, 2010), in the German Black Forest during the Convective and Orographically induced Precipitation Study (COPS; Kalthoff et al., 2009) or in the southwestern Amazon region (Lima and Wilson, 2008). In particular, Lima and Wilson (2008) investigated the possible triggering mechanisms for 315 storms which initiated in the field of view of the radar for a specific day. They found that the gust fronts were the dominant precursors, along with orography and gust front collision. Here, we characterize the occurrence of convection over Sahel, particularly in Niamey (Niger), based on data collected during the African Monsoon Multidisciplinary Analysis (AMMA) field campaign.

During the pre-onset of the West African Monsoon (WAM), the Sahel is characterised by large sensible heat flux and low latent heat flux; the soils are mostly dry (Ramier et al., 2009) and progressively moisten as the first precipitating storms occur. At this time of year, the intertropical convergence zone (ITCZ) has moved northward, leaving the southern part of West Africa under the influence of the monsoon flow. The intertropical discontinuity (ITD), which is the interface between the monsoon flow to the south and the Harmattan (hot and dry) flow to the north, is located a few hundred kilometres north of Niamey (Figure 1(a)). The monsoon flow is stronger at night, as a nocturnal low-level jet forms, bringing southwesterly moist air (Parker et al., 2005). This moist air is then redistributed vertically by the mixing of the planetary convective boundary layer (CBL) (Lothon et al., 2008).

The onset period of the monsoon is favourable to the study of the triggering factors of local deep convection over the Sahelian area. It corresponds to a transition between dry and wet atmosphere and dry and wet surface. Lothon et al. (2011) showed that on 10 July 2006 a convective system initiated around Niamey, with surface-atmosphere exchanges and boundary-layer dynamics (also Couvreux et al., 2012).

In the present study, we extended the observational analysis of the AMMA dataset to the period of 6 to 31 July 2006, in order to analyse more systematically the main features of the convection observed in Sahelian Africa during the pre-onset and onset of the monsoon, and to understand further the transition from dry convection to shallow convection and from shallow to local deep convection.

A description of the data used in this study is given in section 2. The method used to characterise the type of convection for July 2006 and the result of the classification are described in section 3. The analysis of triggering factors and processes differentiating the convection days are documented in section 4. Section 5 summarises and concludes the study.

\section{Data}

The aim of the AMMA campaign was to improve our knowledge and understanding of the WAM and its variability with an emphasis on daily to interannual time-scales (Redelsperger et al., 2006). The Special Observation Period was centred on the peak of the monsoon and took place during summer 2006. Niamey, located in the Sahelian region, lies within one of the three meso-sites of AMMA. For the survey of the Niamey square $\left(12.9-14.3^{\circ} \mathrm{N} ; 1.38-3.23^{\circ} \mathrm{E}\right)$, a large set of instruments was deployed (Lebel et al., 2009). The data used in this study were based on the 3D continuous scans of the Massachusetts Institute of Technology (MIT) radar installed at Niamey and the Atmospheric Radiation Measurement (ARM) mobile facility, especially radiosonde data, surface stations, $95 \mathrm{GHz}$ cloud radar, and an Ultra High Frequency (UHF) wind profiler, all deployed near the radar. Satellite data also provided complementary information. Figure 1(a) locates the area of interest within the mean structure of the WAM during the month of July, and Figure 1(b) indicates the topography in a $100 \mathrm{~km} \times 100 \mathrm{~km}$ area around the MIT radar position.

\subsection{MIT C-band Doppler radar data}

The MIT radar is a C-Band (5.37 cm wavelength) Doppler radar. It was located at Niamey $\left(13.49^{\circ} \mathrm{N}, 2.17^{\circ} \mathrm{E}, 224 \mathrm{~m}\right.$; Figure 1(a)) and operated continuously from July to September 2006 with scans based on continuous threedimensional plan position indicator (PPI) explorations at 

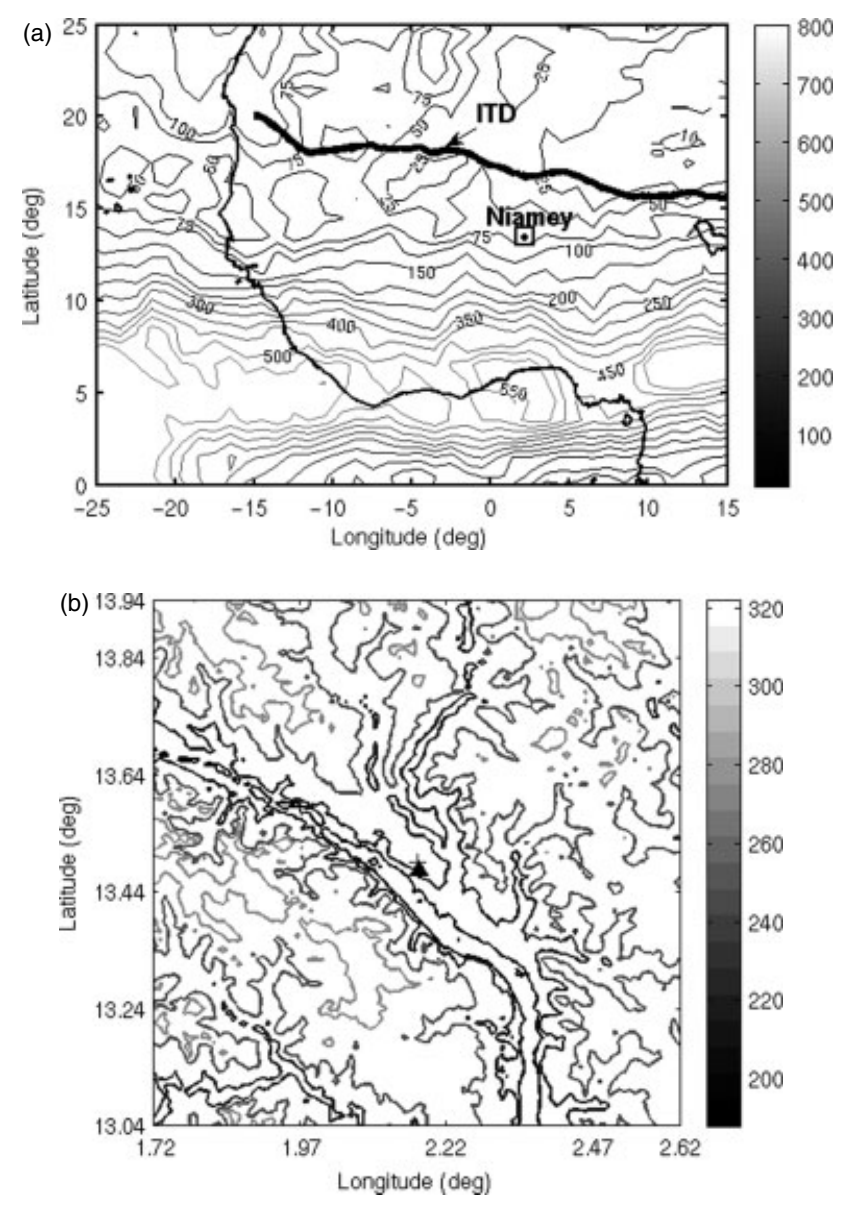

Figure 1. (a) Total rainfall (mm, greyscale contours) for July 2006 in West Africa from the Global Precipitation Climatology Project (GPCP). The thick black line indicates the averaged position of the ITD in July (line of constant dewpoint temperature at $2 \mathrm{~m}$, equal to $15^{\circ} \mathrm{C}$ ). The small square indicates the study area. (b) shows the topography (m) within this study area, with the location of the MIT radar $(+)$ and the ARM site (with radiosonde, UHF wind profiler, and the $95 \mathrm{GHz}$ cloud radar) $(\mathbf{\Delta})$.

10 min time interval. The characteristics of the MIT radar are a $1.4^{\circ}$ beamwidth, a pulse length of $250 \mathrm{~m}$ which is the spatial resolution of the radar measurements, a volume scan at 15 elevation angles $\left(0.5^{\circ}, 1.3^{\circ}, 2.0^{\circ}, 2.8^{\circ}, 3.9^{\circ}\right.$, $4.9^{\circ}, 6.2^{\circ}, 7.5^{\circ}, 9.1^{\circ}, 11.1^{\circ}, 13.5^{\circ}, 16.4^{\circ}, 19.9^{\circ}, 24.1^{\circ}$, $29.2^{\circ}$ ), and a maximum range of $150 \mathrm{~km}$. The ambiguity on distance and Doppler velocity are respectively $158 \mathrm{~km}$ and $12.7 \mathrm{~m} \mathrm{~s}^{-1}$. Optional RHI (Range Height Indicator) scans were performed repeatedly at an azimuth and range depending on the location of the deep convection assuming that these echoes have a large reflectivity and a Doppler velocity close to $0 \mathrm{~m} \mathrm{~s}^{-1}$ in processing. More information and technical details can be found in Russell et al. (2010).

During the AMMA field experiment, the MIT radar was devoted to the observation of the MCSs; however, it also has the capability of detecting boundary-layer clear air echoes and non-precipitating clouds. The echoes in clear air are due to the significant concentration of insects and other biological targets in the thermal structures of the convective boundary layer (Wilson et al., 1994). Knight and Miller (1993) found that the echoes of cumulus clouds from a $5 \mathrm{~cm}$ radar have reflectivity factors larger than $0 \mathrm{dBZ}$, but this threshold probably varies with the area of interest and the season considered.

The velocity volume processing (VVP; Waldteufel and Corbin, 1979) of the MIT radar data allowed us to estimate the vertical profile of the horizontal mean wind field parameters at a horizontal scale of about $30 \mathrm{~km}$ radius. This technique is based on the hypothesis of local linearity of the mean wind field within elementary cylindrical slices. Here, a $100 \mathrm{~m}$ vertical depth and a $30 \mathrm{~km}$ horizontal radius were chosen for the dimensions of these elementary cylindrical slices. For the present study, we used this technique to retrieve the vertical profiles of horizontal divergence, for which the VVP statistical error is around $0.03 \times 10^{-4} \mathrm{~s}^{-1}$. A more detailed description of the VVP analysis and of the errors made on divergence estimates is given in the Appendix.

The reflectivity and Doppler velocity data obtained in the PPI in spherical coordinates were interpolated onto a Cartesian grid $(100 \mathrm{~km} \times 100 \mathrm{~km})$ (Cressman, 1959). This interpolation used a weighting function depending on the distance between a grid point and the observed data point within an ellipsoid of influence centred on the grid point and defined by its horizontal and vertical radii $R_{x y}$ and $R_{z}$, respectively. In the low levels of the atmosphere, horizontal and vertical radii of influence were chosen as $600 \mathrm{~m}$ and $350 \mathrm{~m}$, respectively. In the upper levels (above $600 \mathrm{~m}$ ), they were both chosen as $1000 \mathrm{~m}$, due to the smaller density of data points in this region. A sliding average was also applied to the two layers. The horizontal planes in the volume scan data at different heights provided a view of the 3D organization of the reflectivity field or Doppler velocity in clear and cloudy air. This method allowed us to characterise the morning clear-air organization in the CBL and the type of convection observed during the afternoon.

\subsection{ARM mobile facility instruments}

\subsubsection{UHF wind profiler data}

The UHF wind profiler was installed at Niamey Airport $1.6 \mathrm{~km}$ from the MIT radar (Figure 1). It was operated continuously at $915 \mathrm{MHz}$ from April 2006 to January 2007 and was part of the Atmospheric Radiation Measurement (ARM) Mobile Facility (Miller and Slingo, 2007). The power $(500 \mathrm{~W})$ of this profiler was emitted in five successive beams, one vertical and four oblique. The principle is based on the backscattered signals from turbulence-induced atmospheric refractive index fluctuations at a scale of half the radar wavelength (Bragg scattering), transported by the flow (Balsley and Gage, 1982). The radar reflectivity is related to the structure parameter of the turbulence refractive index fluctuations $C_{n}^{2}$ (Gossard et al., 1982) defined in the inertial subrange. The UHF profiler was run in two modes: the vertical resolution at low mode was $90 \mathrm{~m}$ and at high mode $210 \mathrm{~m}$. This profiler can also function in precipitation conditions. More information about this radar and its observations during AMMA can be found in Kalapureddy et al. (2010), who demonstrated the interactions between AEJ, the boundary layer and the Saharan heat low. The UHF wind profiler was used at high mode for the study of the evolution of the wind profile in the first $5 \mathrm{~km}$, and at low mode for the estimation of the atmospheric boundary-layer depth $Z_{\mathrm{i}}$ at $15 \mathrm{~min}$ time resolution. $Z_{\mathrm{i}}$ is estimated with the sudden increase of $C_{n}^{2}$ with height associated with the sharp changes in atmospheric temperature and humidity usually observed at the boundary-layer top (Doviak and Zrnić, 1993; Angevine et al., 1994; Jacoby et al., 2002). 


\subsubsection{Radiosonde data}

During the study period, four radiosondes were launched every day from Niamey at 0530, 1130, 1730, and 2330 UTC, close to the synoptic hours.

The radiosonde data were used to estimate the planetary boundary-layer height based on the maximum gradient of potential temperature to validate the estimates of $Z_{\mathrm{i}}$ with the UHF profiler. A good correlation between the two estimates was found at 1130 UTC (not shown). The radiosonde data were also used to analyse the large-scale factors that can sometimes favour the triggering of deep convection. The parameters of instability (convective available potential energy and convective inhibition - CAPE and CIN) were computed. The radiosonde data were also used to test the framework of Findell and Eltahir (2003) based on two atmospheric indicators: convective trigger potential $(C T P)$ and humidity index $\left(H I_{\text {low }}\right)$. The $C T P$ is determined by integrating the area between the observed temperature sounding and a $200 \mathrm{hPa}$ thick moist adiabat originating $100 \mathrm{hPa}$ above the surface:

$$
C T P=\int_{z_{\left(P_{\text {surf }}-100 \mathrm{hPa}\right)}}^{z_{\left(P_{\text {surf }}-300 \mathrm{hPa}\right)}} g\left(\frac{T v_{\text {parcel }}-T v_{\text {env }}}{T v_{\text {env }}}\right) \mathrm{d} z .
$$

Here $T v_{\text {parcel }}$ is the virtual temperature of a moist air parcel lifted adiabatically from the level $100 \mathrm{hPa}$ above the surface, while $T v_{\text {env }}$ is the temperature of the observed profile. The layer of integration starts about $1000 \mathrm{~m}$ above the surface, and its depth is about $2000 \mathrm{~m}$. That covers the interface entrainment zone between the CBL and the free troposphere. The humidity index in the low atmosphere $\left(\mathrm{HI}_{\text {low }}\right)$ is a variation on the humidity index (Lytinska et al., 1976), and is the sum of the dewpoint depressions at 950 and $850 \mathrm{hPa}$.

\subsubsection{Surface flux}

The surface fluxes were provided by the ARM station installed at Niamey (Figure 1). The data from this station were also used to estimate the Monin-Obukhov length $L$, and the ratio $-Z_{\mathrm{i}} / L$ which characterizes the boundary-layer instability.

\subsection{4. $95 \mathrm{GHz}$ Cloud radar}

Additional information about the vertical structure of the atmosphere was given by the $\mathrm{W}$-band $95 \mathrm{GHz}$ cloud radar also installed at the ARM site of Niamey. This Doppler radar pointed vertically, enabling us to determine cloud boundaries (e.g. cloud bases and tops; Bouniol et al., 2012). It was used in this study to assist in the classification of the convection days, especially when the MIT radar was not functional, which occurred on one clear day (24 July 2006).

\subsection{Satellite data}

Satellite brightness temperature at $10.8 \mu \mathrm{m}$ from the Meteosat Second Generation (MSG) satellite was used to assess the location, from the top of the atmosphere, of deep convective events observed by the MIT radar from the ground. This allowed us to follow its evolution further outside the radar range, with a $15 \mathrm{~min}$ time interval and about $3 \mathrm{~km}$ resolution. Following Mathon and Laurent
(2001), deep convection was identified from the satellite data using a maximum brightness temperature threshold of $233 \mathrm{~K}$.

\section{Diagnosis of convection days}

\subsection{Overview of the studied period}

The onset stage of the African summer monsoon is linked to an abrupt latitudinal shift (of the order of $5^{\circ}$ ) of the ITCZ between its position in May-June and July-August (Sultan and Janicot, 2003). During this period there is a thickening of the monsoon layer associated with an extended penetration of moisture into West Africa. In 2006, the WAM onset occurred around 10-15 July (Janicot et al., 2008; Lothon et al., 2008). Consequently, our study period falls within the onset period, with a first period during the moistening phase (early monsoon, 6-15 July) and a second period during the active monsoon (16-31 July).

Figure 1(a) shows the mean position of the ITD in July 2006 and the cumulative rainfall from the Global Precipitation Climatology Project (GPCP) calculated for July 2006. The ITD is located to the north of Niamey and the maximum rainfall in West Africa occurred between 3 and $8^{\circ} \mathrm{N}$. Around Niamey, the cumulative rainfall over the month of July reached less than $200 \mathrm{~mm}$.

This period is also documented in Figure 2 by the time-height sections of the horizontal wind speed and mixing ratio derived from the UHF wind profiler and radiosonde data, respectively.

As shown in Figure 2(a), from 6 to 31 July 2006, southwesterly monsoon flow occurred at the low levels (up to $1000 \mathrm{~m}$ ) and the easterly flow from the AEJ occupied the mid levels. This period is usually associated with diurnal variations of the AEJ activity in conjunction with the ITD variability (Kalapureddy et al., 2010) and perturbations in the cycle of the nocturnal low-level jet (Lothon et al., 2008) due to the deep convection. The AEJ activity was intense between 13 and 25 July and moderate at the beginning and end of the period.

Figure 2(b) shows the large humidity gradient between the wet monsoon flow (low-level southwest flow) and the dry Saharan air layer (SAL) (mid-level easterly flow). The diurnal cycle of the mixing ratio in the low levels varied more from one day to another at the beginning of the period. The monsoon flow was deeper at the end of the studied period.

\subsection{Classification of days}

Based on the data described in the previous section, we analyzed the occurrence of deep convection within a radius of $50 \mathrm{~km}$ around the MIT radar (Figure 1(a)). Four types of convection days were observed over Niamey:

(i) afternoon locally initiated deep convection (LC),

(ii) shallow convection ( $\mathrm{SH})$,

(iii fair weather with clear sky all day (FW) and

(iv) propagating deep convection (PC) passing over the area at any time of the day.

Those four types of situation are explained in more detail below. 

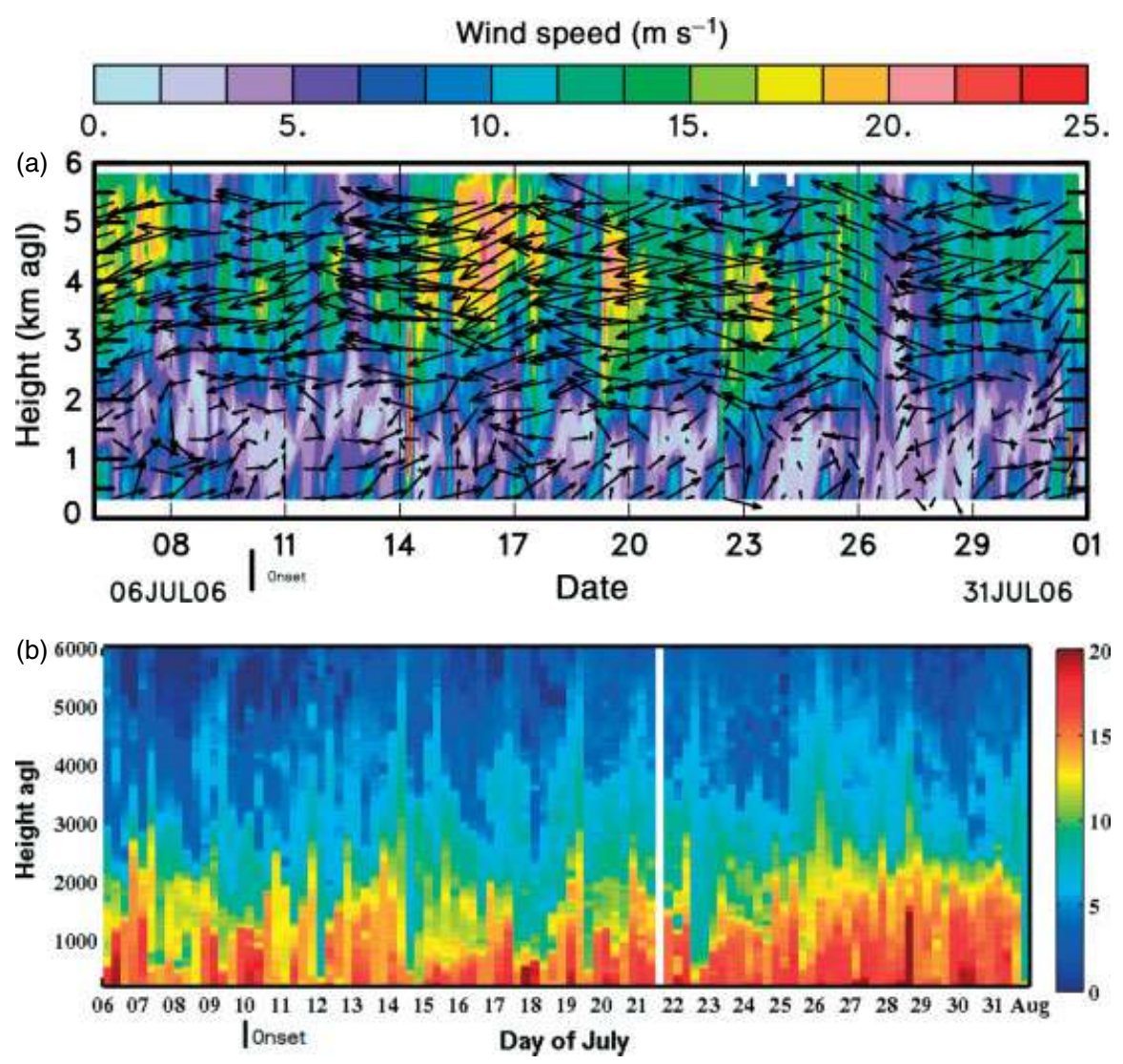

Figure 2. Time-height section of (a) the horizontal wind $\left(\mathrm{m} \mathrm{s}^{-1}\right)$ measured with the UHF wind profiler and (b) mixing ratio $\left(\mathrm{g} \mathrm{kg}^{-1}\right)$ measured by the radiosondes at Niamey from 6 to 31 July 2006. In (a), a leftward arrow represents an easterly wind.

\subsubsection{Afternoon locally initiated deep convection (LC)}

This type of day was defined when deep convection triggering was actually observed within the $50 \mathrm{~km}$ radius of the MIT radar. It is investigated from the PPI and horizontal crosssection of MIT radar reflectivity (cf. section 2.1) of $100 \mathrm{~km}$ $\times 100 \mathrm{~km}$ centred on the position of the radar, obtained every $10 \mathrm{~min}$ at different heights. Those images allowed us to determine the time and location of the onset of convection, and to follow its development and propagation. Deep convection is defined with a minimum threshold on radar reflectivity of $30 \mathrm{dBZ}$ (Wilson and Schreiber, 1986; Wilson and Muller, 1993) and a vertical extension greater than $6 \mathrm{~km}$. To confirm this classification, the infrared brightness temperature $(233 \mathrm{~K})$ from MSG were used in the same area of the MIT radar. The $95 \mathrm{GHz}$ radar data completed the analysis, and were used to determine the depth of the convection over its location, especially when deep convection developed above the radar.

The first convective cell observed in the MIT radar scan volume was tracked every $10 \mathrm{~min}$ to evaluate the depth at which it developed, how it propagated and whether it generated a circular gust front. Note that $10.8 \mu \mathrm{m}$ brightness temperature cannot usually detect the gust fronts. No criteria were based on ground observations because convective rains may form away from the station network or AMMA-Catch rain gauges installed in the vicinity of Niamey.

Figure 3 shows the reflectivity pattern in horizontal cross-sections at $1000 \mathrm{~m}$ height and vertical zonal crosssections $3 \mathrm{~km}$ to the south of the radar, at selected times in the afternoon (1510, 1600, and 1700 UTC), showing the evolution of the afternoon deep convection on 27 July.
The first deep convective cell appeared around 1500 UTC on the vertical cross-section as a column of reflectivity larger than $9 \mathrm{dBZ}$ between 2 and $6 \mathrm{~km}$ height (not shown). The convective cell extended $5 \mathrm{~km}$ horizontally and more than $7 \mathrm{~km}$ vertically (Figure $3(\mathrm{~d})$ ) and propagated to the northwest $10 \mathrm{~min}$ later. Other convective cells developed in the northwest and moved to the northwest of the radar (Figure 3(b, c, e, f)).

This is a typical example of afternoon local deep convection occurring over Niamey. Eight other similar cases of locally initiated deep convection were found during the 6-31 July period.

\subsubsection{Shallow convection days (SH)}

This category corresponds here to the development of shallow cumulus or congestus clouds which dissipate quite rapidly. The shallow convection days are defined using the MIT radar observations when the convective structures have

(i) reflectivity within the convective structure smaller than $30 \mathrm{dBZ}$,

(ii) vertical extension less than $6 \mathrm{~km}$,

(iii) life-time less than $40 \mathrm{~min}$.

The criteria (ii) and (iii) need to be met for the day to be classified in this class. The criterion (i) is met most of the time. The $95 \mathrm{GHz}$ cloud radar reflectivity helped to verify the vertical extension of the clouds. The MODIS imagery was also used to confirm the presence of cumulus clouds seen by the MIT radar in its scan volume at 1330 UTC. Sometimes congestus clouds gave some precipitation, as for example on 

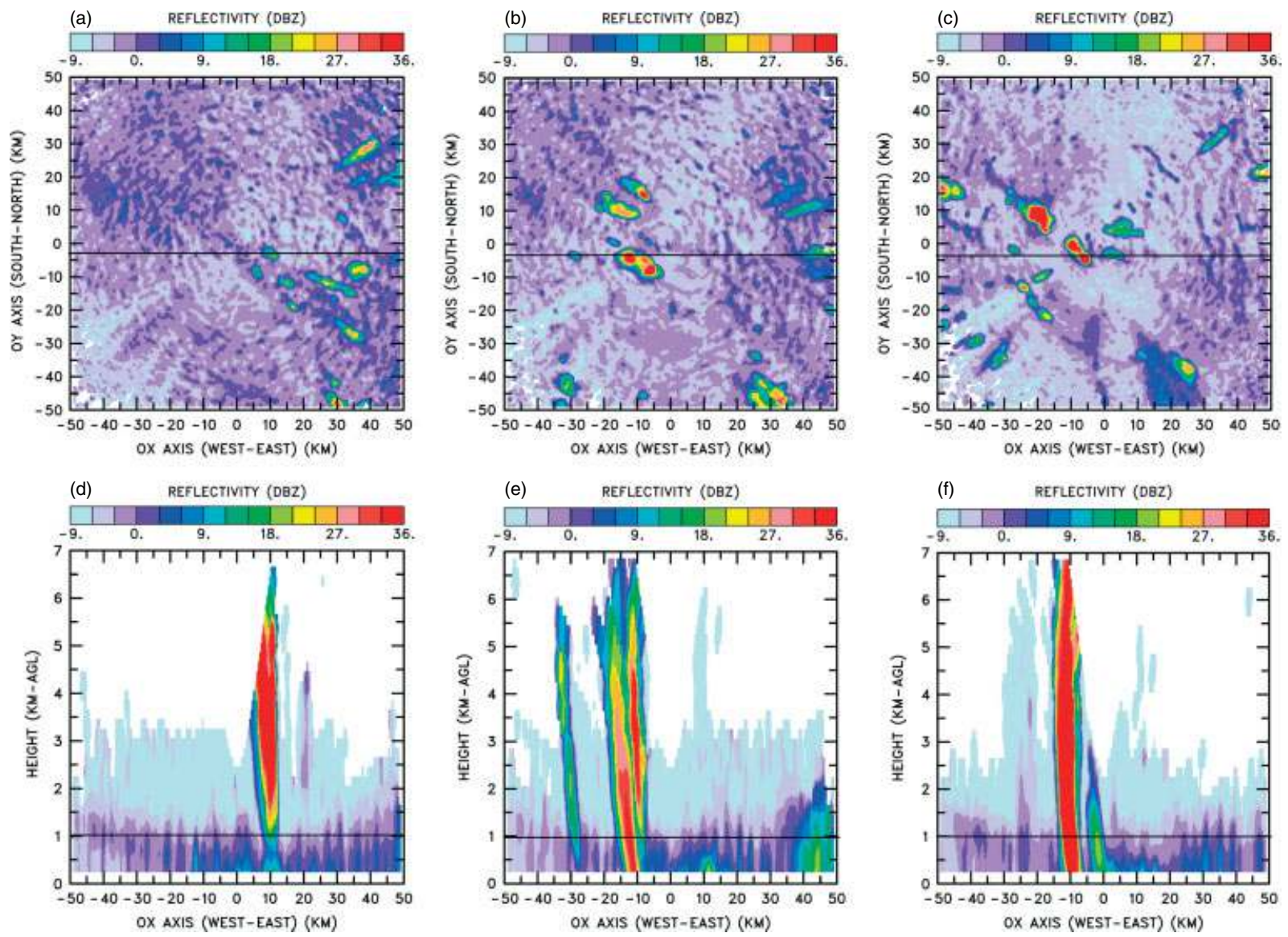

Figure 3. Reflectivity interpolated onto (a, b, c) horizontal cross-sections at $Z=1000 \mathrm{~m}$ agl, and (d, e, f) vertical cross-sections at $Y=-3 \mathrm{~km}$, at (a, d) 1510 UTC, (b, e) $1600 \mathrm{UTC}$, and (c, f) $1700 \mathrm{UTC}$ on 27 July 2006. The MIT radar was positioned at the reference point $(X=0, Y=0)$. Here $R_{x y}=1000 \mathrm{~m}$ and $R_{z}=500 \mathrm{~m}$ are used for the horizontal and vertical sections. Straight lines indicate positions of the vertical and horizontal cross-sections shown. High reflectivity in the southeast sector $(X=30 \mathrm{~km}, Y=0 \mathrm{~km})$ at $1600 \mathrm{UTC}$ are second-trip echoes from long-distance deep convective systems.

13 July 2006 when $4 \mathrm{~mm}$ were recorded at Torodi between 1400 and 1600 UTC. As an example of shallow convection, Figure 4 shows the MIT reflectivity pattern on 13 July 2006, in horizontal cross-sections at $1000 \mathrm{~m}$ and vertical zonal cross-sections made within two congestus clouds later in the afternoon. Figure 4(a) shows the organisation within the CBL. Rolls are observed to the northeast, east and south of the MIT radar, while thermal cells are observed to the west.

Cloud streets of PBL cumulus are observed to the east of the radar on the MODIS image, whereas larger higher clouds are observed to the west, which hide the lower troposphere (Figure 4(c)). The vertical cross-section (Figure 4(b)) shows higher reflectivity values larger than $5 \mathrm{dBZ}$ on the east side between 1.5 and $3 \mathrm{~km}$ height, which might correspond to cumulus clouds. Knight and Miller (1993) found a reflectivity factor threshold of $0 \mathrm{dBZ}$ for $5 \mathrm{~cm}$ wavelength, above which the backscattered radar signal can be assumed to mostly correspond to hydrometeors and more rarely to other particulate material such as insects. However both Figures $4(\mathrm{a}, \mathrm{b})$ show that we observe echoes with reflectivity larger than $0 \mathrm{dBZ}$ in clear air. The relatively high values of reflectivity reaching the low levels in Figure 4(b), for example, correspond to clear-air thermal structures (between $X=-6 \mathrm{~km}$ and $+6 \mathrm{~km}$, and below $Z=1.5 \mathrm{~km}$ ).

Figures $4(\mathrm{~d}-\mathrm{f})$ show the echoes of two weakly precipitating congestus clouds located respectively 10 and $15 \mathrm{~km}$ south of the radar at 1640 UTC. These clouds are observed on Figure $4(\mathrm{e}, \mathrm{f})$ with depth close to $6 \mathrm{~km}$ and with reflectivity lower than $30 \mathrm{dBZ}$. These clouds dissipate within $40 \mathrm{~min}$

This is a typical example of a shallow convection day. We found four cases during the study period. On two days, 13 and 30 July, we found congestus clouds in the studied area.

\subsubsection{Fair weather days $(F W)$}

This class is defined by fair weather with clear sky all day, with no echoes of high reflectivity on horizontal and vertical cross-sections in the volume scanned by the MIT radar. We confirmed that our clear sky definition is consistent with the results obtained with the $95 \mathrm{GHz}$ radar (cf Bouniol et al. (2012)). Three cases of clear-sky days were found. During one of them (24 July) the MIT radar was not working, and we used the $95 \mathrm{GHz}$ cloud radar measurements, the $10.8 \mu \mathrm{m}$ MSG brightness temperature and the MODIS images to define the type of convection on this day. On 21 July 2006, the atmosphere above the volume scan by the MIT radar was marked by the passage of mid-level clouds (seen by the satellite MSG and $95 \mathrm{GHz}$ ) in the early afternoon. This day was therefore discarded from this class, although the CBL was dry all day.

\subsubsection{Propagating deep convection days (PC)}

Propagating deep convection is defined when deep convection formed outside of the scan volume of the MIT 
(a)

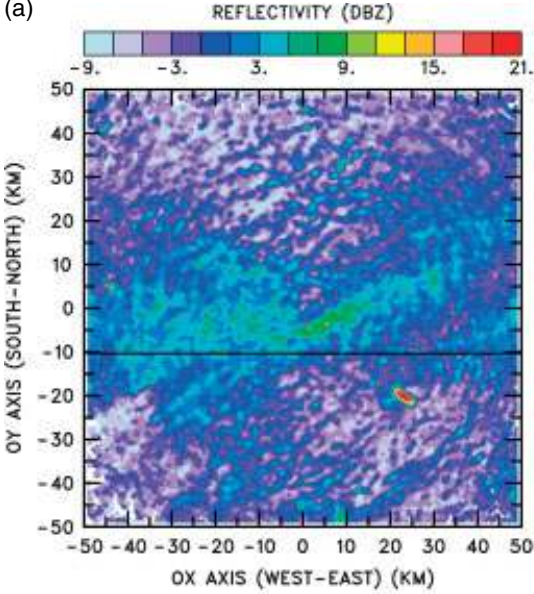

$\mathrm{Z}=1000 \mathrm{~m}$

(d)
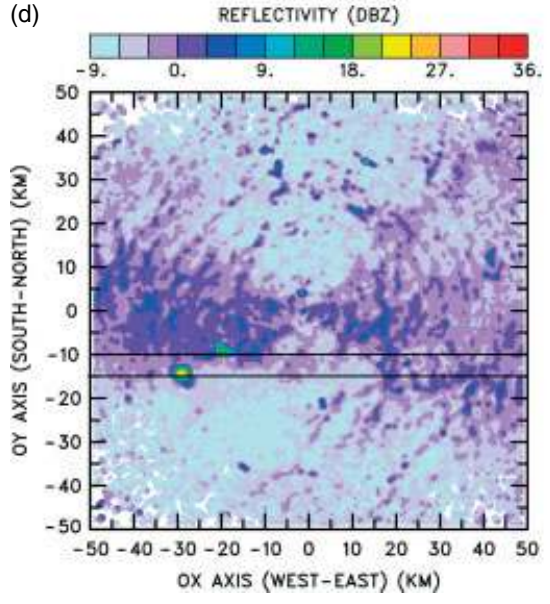

$\mathrm{Z}=1000 \mathrm{~m}$ (b)

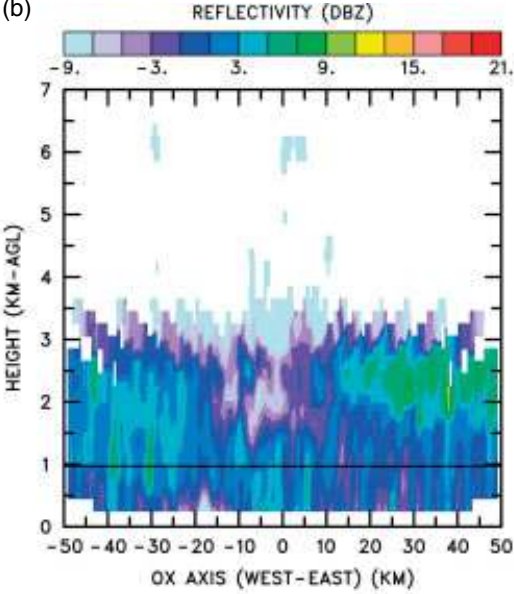

$Y=-10 \mathrm{~km}$

(e)

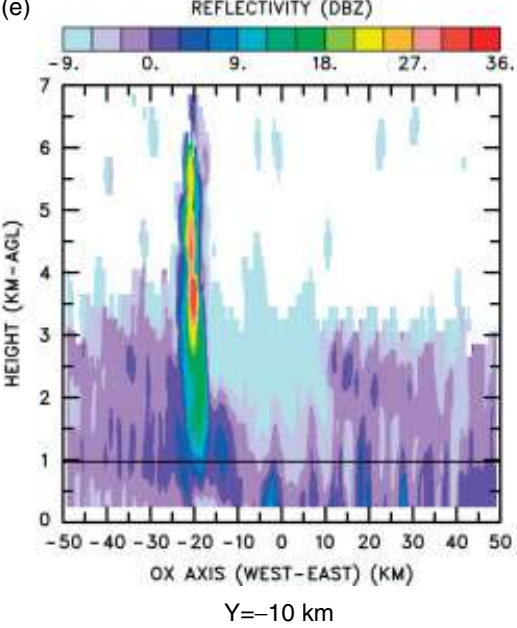

(c)

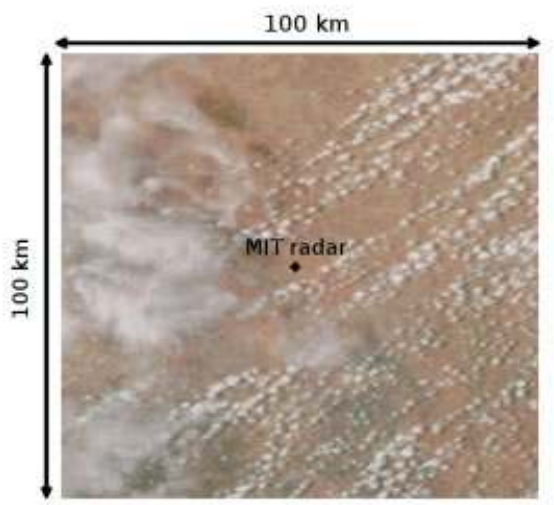

MODIS at 1330 UTC

(f)
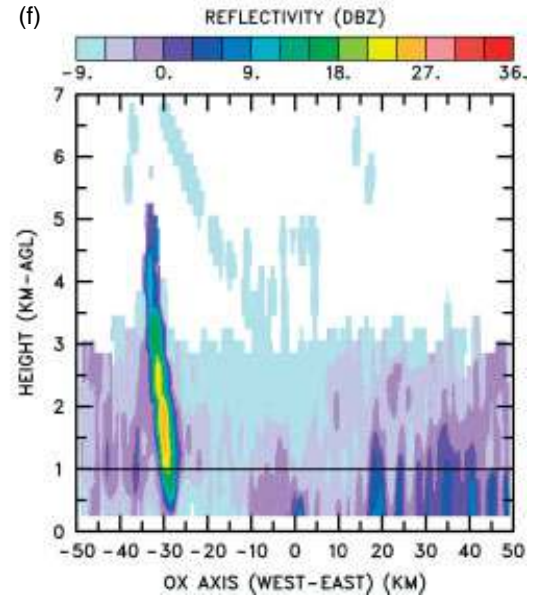

$\mathrm{Y}=-15 \mathrm{~km}$

Figure 4. Example of a shallow convection case, on 13 July 2006, at (a, b, c) 1330 UTC and (d, e, f) 1640 UTC. MIT radar interpolated reflectivity (with influence radii as in Figure 3) onto (a,d) horizontal cross-sections at $Z=1000 \mathrm{~m}$, and (b, e, f) vertical cross-sections south of the radar - (b, e) at $Y=-10 \mathrm{~km}$ and (f) at $Y=-15 \mathrm{~km}$. Straight lines indicate the vertical and horizontal cross-sections shown. Colour scales are different between (a, b) and $(\mathrm{d}, \mathrm{e}, \mathrm{f})$ because in $(\mathrm{a}, \mathrm{b})$ low reflectivity is chosen for the observation of the clear air organisation.

radar (usually to the east) and propagated (westward) across the study area. These convective cells were usually large MCSs seen at night or early morning. Note that a day is considered in this class when the MCS passed through the area in the morning of the day, or during the previous night. An example of this class is given by Barthe et al. (2010); ten days fell into this category.

\subsubsection{Results of the classification}

Table 1 summarises the classification of the diurnal convection during our study period. Over the 26 days studied, we found: nine days with afternoon locally initiated deep convection (LC), ten days with propagating deep convection (PC), four days with shallow convection $(\mathrm{SH})$, three days with fair weather (FW), and one unclassified day. Among LC cases, five (6, 8, 10, 11 and 12 July) were observed during the pre-onset and four (20,26, 27 and 28 July) in the onset periods. The transition period between the pre-onset and onset was marked by propagating deep convection or fair weather. For this period, shallow convection was observed either after local or propagating convection days, but never after fair weather. This classification shows that the afternoon LC occurrence is as large as that of MCSs over Niamey during this early monsoon period.
Tables 2 to 5 summarize the main features of the observed diurnal cycle of convection each day, for each class. Information about clear-air CBL organisation, transition times, occurrence of convergence lines or gust fronts are shown, which will be discussed in the following subsections.

\subsection{Convergence lines}

The role of convergence lines in the initiation of deep convection is well documented (Byers and Abraham, 1949; Purdom, 1976; Wilson and Schreiber, 1986; Koch and Ray, 1997; Klüpfel et al., 2012). Wilson et al. (1994) used dualDoppler radar analyses and found that thin line echoes usually correspond to updraught regions. Here, convergence lines were observed in the horizontal planes of reflectivity deduced from the MIT radar data. They can be seen in the infrared channel satellite data and visible satellite cloud images, when they are topped by cumulus clouds.

Figure 5 presents horizontal and vertical cross-sections of reflectivity at $Z=600 \mathrm{~m}$ and $Y=15 \mathrm{~km}$ respectively at $1500,1550,1620$ and 1640 UTC on 6 July 2006, together with the visible satellite cloud images from MSG at 1500, 1530, 1630 and 1645 UTC on this day. In the morning, rolls were observed in the CBL and they persisted until the early afternoon (not shown). Later, a convergence 
Table 1. Types of convection observed in the volume scan of the C-band MIT radar $(100 \mathrm{~km} \times 100 \mathrm{~km})$ from 6 to 31 July 2006 over Niamey. 21 July had clear sky in the morning and mid-level clouds in early afternoon, and is not classified.

\begin{tabular}{|c|c|c|c|c|c|c|c|c|c|c|c|c|c|}
\hline Day (July 2006) & 06 & 07 & 08 & 09 & 10 & 11 & 12 & 13 & 14 & 15 & 16 & 17 & 18 \\
\hline Type of convection & $\mathrm{LC}$ & PC & $\mathrm{LC}$ & PC & $\mathrm{LC}$ & $\mathrm{LC}$ & $\mathrm{LC}$ & $\mathrm{SH}$ & $\mathrm{PC}$ & PC & FW & PC & FW \\
\hline Day (July 2006) & 19 & 20 & 21 & 22 & 23 & 24 & 25 & 26 & 27 & 28 & 29 & 30 & 31 \\
\hline Type of convection & $\mathrm{PC}$ & $\mathrm{LC}$ & - & PC & $\mathrm{SH}$ & FW & PC & $\mathrm{LC} / \mathrm{PC}$ & LC & $\mathrm{LC}$ & $\mathrm{SH}$ & $\mathrm{SH}$ & PC \\
\hline
\end{tabular}

LC denotes afternoon local deep convection, PC propagating deep convection at all times, SH shallow convection, and FW fair weather without cumulus.

Table 2. Course of the different convection days from 6 to 31 July 2006 over Niamey on days with afternoon locally initiated deep convection.

\begin{tabular}{lccccccccccccccccc}
\hline Day & BL $_{\text {ORG }}$ & Time $_{0}$ & $-Z_{\mathrm{i}} / L$ & $Z_{\mathrm{i}}$ & $H$ & BL $_{\mathrm{ORG}}$ & Time $_{1}$ & $-Z_{\mathrm{i}} / L$ & $Z_{\mathrm{i}}$ & $H$ & Shear & Time deep $^{\text {GF }}$ & DR & NC & CL \\
\hline 06 & rolls & 0841 & 15 & 745 & 289 & cells & 1341 & 364 & 1630 & 317 & 3.9 & 1501 & yes & $30(\mathrm{WNW})$ & line & yes \\
08 & rolls & 0935 & 11.7 & 477 & 220 & cells & 1251 & 95 & 1858 & 310 & 3.7 & 1541 & yes & $30(\mathrm{NW})$ & 0 & yes \\
10 & rolls & 0941 & 78 & 794 & 316 & cells & 1231 & 206 & 1684 & 319 & 1.8 & 1541 & yes & $5(\mathrm{E})$ & 3 & - \\
11 & rolls & 0821 & 16 & 905 & 204 & cells & 1241 & 83 & 1700 & 272 & 3 & 1511 & yes & $20(\mathrm{~S})$ & 6 & yes \\
12 & rolls & 0927 & 10 & 593 & 183 & cells & 1251 & 87 & 1641 & 260 & 3.3 & 1641 & yes & $20(\mathrm{~S})$ & 4 & - \\
20 & rolls & 0951 & 23 & 711 & 160 & cells & 1301 & 137 & 1290 & 202 & 2.7 & 1621 & yes & $50(\mathrm{E})$ & 2 & - \\
26 & rolls & 1031 & 194 & 673 & 123 & cells & 1201 & 355 & 802 & 77 & 4.1 & 1301 & yes & $30(\mathrm{NW})$ & 2 & - \\
27 & cells & 0931 & 22 & 667 & 162 & - & - & - & - & - & - & 1511 & - & $11(\mathrm{SE})$ & - & - \\
28 & rolls & 0951 & 109 & 596 & 162 & cells & 1331 & 113 & 1636 & 120 & 2.8 & 1721 & yes & $10(\mathrm{SW})$ & 1 & - \\
\hline
\end{tabular}

$\mathrm{BL}_{\mathrm{ORG}}$ denotes the boundary-layer organization (rolls or thermal cells).

Time $_{0}$, Time $_{1}$, Time $_{\text {deep }}$ are the times (UTC) of the start of organisation, of the transition from rolls to thermal cells or thermal cells to rolls, and of deep convection initiation.

$Z_{\mathrm{i}}=$ atmospheric boundary-layer top $(\mathrm{m}), L=$ Monin-Obukhov length $(\mathrm{m}), H=$ sensible heat flux $\left(\mathrm{W} \mathrm{m} \mathrm{m}^{-2}\right)$.

Shear $\left(10^{-3} \mathrm{~s}^{-1}\right)$ is estimated from the VVP method between 100 and $1000 \mathrm{~m}$.

$\mathrm{GF}=$ gust front; $\mathrm{DR}=$ distance in $\mathrm{km}$ (and direction) of the initiation point from the radar;

$\mathrm{NC}=$ number of convective cells formed after the density current passage; $\mathrm{CL}=$ convergence line.

- indicates that no phenomena were observed.

Table 3. As Table 2, but for shallow convection days.

\begin{tabular}{lcccccccccccc}
\hline Day & BL ORG & Time $_{0}$ & $-Z_{i} / L$ & $Z_{i}$ & $H$ & BL ORG & Time $_{1}$ & $-Z_{i} / L$ & $Z_{i}$ & $H$ & Shear \\
\hline 13 & rolls & 0911 & 14 & 715 & 167 & cells & 1231 & 99 & 1766 & 321 & 3.3 \\
23 & rolls & 1031 & 34 & 658 & 167 & cells & 1301 & 72 & 1101 & 190 & 5.2 \\
29 & rolls & 1011 & 17 & 617 & 273 & cells & 1201 & 95 & 1521 & 262 & 4.9 \\
30 & rolls & 0951 & 45 & 611 & 208 & cells & 1241 & 67 & 1500 & 176 \\
\hline
\end{tabular}

Table 4. As Table 2, but for days with fair weather/clear skies.

\begin{tabular}{lccccccccccc}
\hline Day & BL $_{\text {ORG }}$ & Time $_{0}$ & $-Z_{i} / L$ & $Z_{i}$ & $H$ & BL ORG & Time $_{1}$ & $-Z_{i} / L$ & $Z_{i}$ & $H$ \\
\hline 16 & rolls & 0911 & 12 & 590 & 248 & cells & 1321 & 70 & 1188 & 313 \\
18 & rolls & 0911 & 16 & 449 & 171 & cells & 1331 & 245 & 1168 & 220 & 3.8 \\
24 & - & - & - & - & - & - & - & - & - \\
\hline
\end{tabular}

- denotes missing data.

line developed north of the radar (Figure 5(a)), partly topped by cumulus clouds (Figure 5(i)). After 1500 UTC the clouds rapidly developed into towering cumulus on the western side of the MIT scope (Figure 5(b, f, i)), and a few minutes later the radar reflectivity aloft reached $50 \mathrm{dBZ}$. Deeper convective cells triggered later along the line (Figure 5(d, h, l)). According to the satellite data, the length of the line exceeded $100 \mathrm{~km}$ (Figure $5(\mathrm{k}, \mathrm{l})$ ), with a second line immediately to the east and a few kilometres north of this line. Another line of higher reflectivity was observed south of the MIT radar, which also partly materialized into a cloud street (Figure $5(i, j)$ ). Deep convection was not triggered within this line. However, it is interesting to note that the southern line came from a clear-air roll which persisted over time from the morning to the afternoon. The same scenario was observed on 29 July, with the formation of a convergence line that did not initiate deep convection. On the other hand, convection was triggered within a convergence line on two other days. On 8 July (not shown), the convergence line appeared to be built from a persistent roll structure. Therefore, convergence lines appear as one of the precursors of deep convection initiation in the Sahel, as found by Klüpfel et al. (2012). In the case described above, we found that the deep convection was associated with a gust front moving in a circular shape (Figure $5(b, c)$ ). The occurrence of this phenomenon is discussed in the following section.

\subsection{Gust fronts}

Density currents generated by the downdraught of thunderstorms create low-level cold pools characterised by large differences from the ambient air. The thermodynamic 
Table 5. As Table 2, but for propagating convection days.

\begin{tabular}{|c|c|c|c|c|c|c|c|c|c|}
\hline Day & Time $_{\text {passage }}$ & $\mathrm{BL}_{\mathrm{ORG}}$ & time $_{0}$ & $-Z_{i} / L$ & $Z_{i}$ & $\mathrm{BL}_{\mathrm{ORG}}$ & time $_{1}$ & $-Z_{i} / L$ & $Z_{i}$ \\
\hline 07 & $2111(\mathrm{D}-1)$ & cells & 1011 & 4 & 296 & rolls & 1341 & 40 & 577 \\
\hline 09 & $2300(\mathrm{D}-1)$ & cells & 1041 & 26 & 371 & rolls & 1221 & 47 & 924 \\
\hline 14 & 0421 & - & - & - & - & - & - & - & - \\
\hline 15 & 0121 & cells & 1031 & 32 & 264 & rolls & 1351 & 46 & 612 \\
\hline 17 & 0541 & cells & 1231 & 4 & - & - & - & - & - \\
\hline 19 & 0421 & - & - & - & - & - & - & - & - \\
\hline 22 & 0800 & cells & 1611 & 6 & 277 & - & - & - & - \\
\hline 25 & 0600 & - & - & - & - & - & - & - & - \\
\hline 31 & 0840 & - & - & - & - & - & - & - & - \\
\hline
\end{tabular}

Time $\mathrm{passage}=$ time of deep convection passage; $(\mathrm{D}-1)$ denotes the previous day.

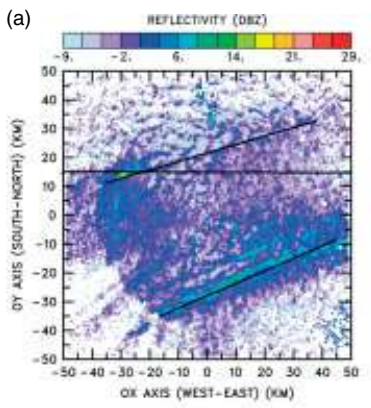

(e)

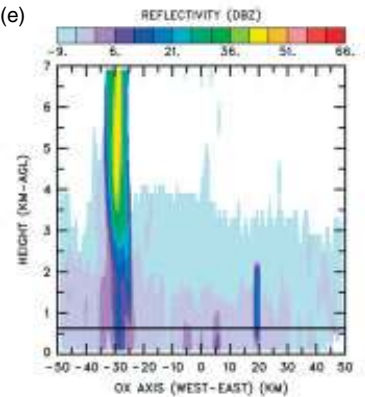

(i)

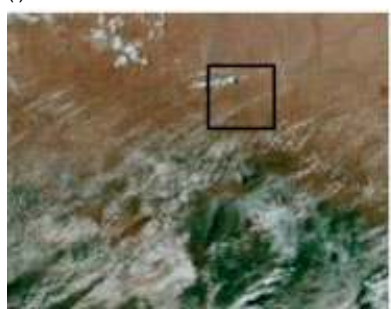

(b)

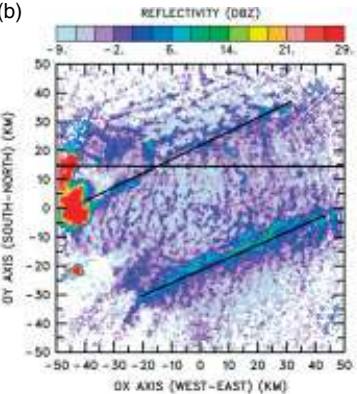

(f)

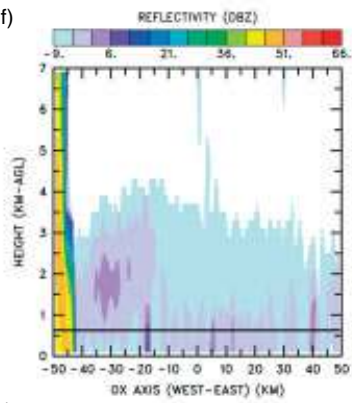

(j)

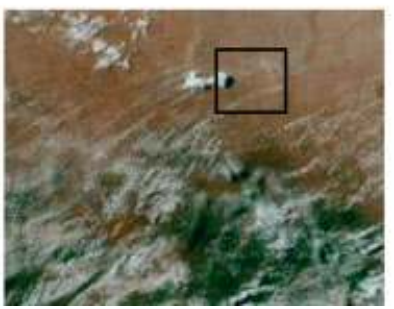

(c)

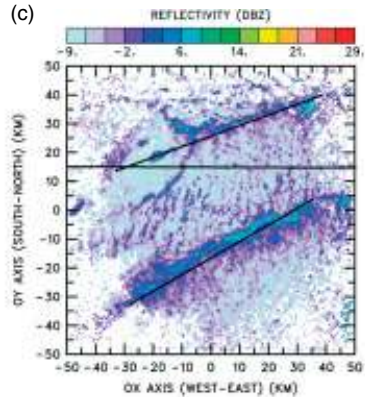

(g)

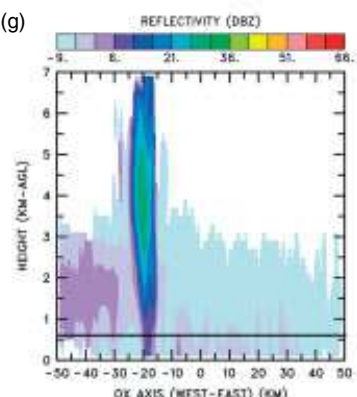

$(\mathrm{k})$

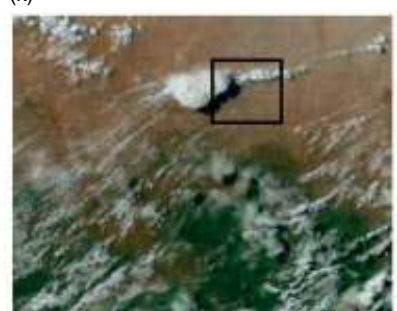

(d)

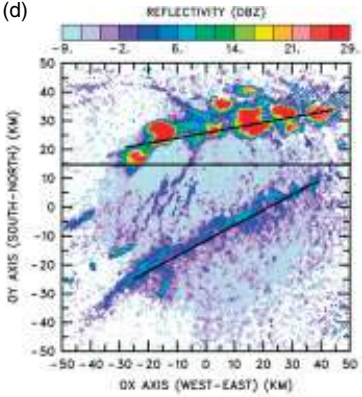

(h)

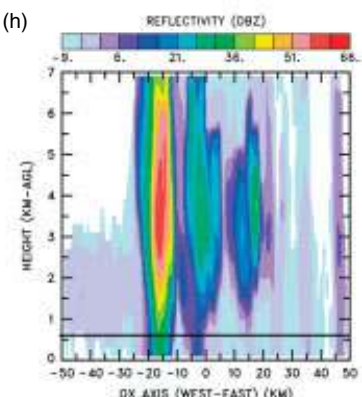

(I)

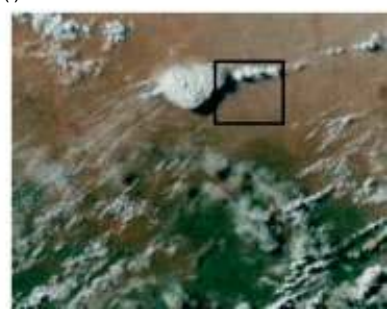

Figure 5. Reflectivity on 6 July 2006 interpolated onto (a, b, c, d) horizontal cross-sections at $Z=600 \mathrm{~m}$ agl, (e, f, g, h) vertical cross-sections at $Y=15 \mathrm{~km}$, at (a, e) $1500 \mathrm{UTC},(\mathrm{b}, \mathrm{f}) 1550 \mathrm{UTC},(\mathrm{c}, \mathrm{g}) 1620 \mathrm{UTC}$, and $(\mathrm{d}, \mathrm{h}) 1640$ UTC. Here $R_{x y}=600 \mathrm{~m}$ and $R_{z}=350 \mathrm{~m}$ are used for the horizontal sections and $R_{x y}=1000 \mathrm{~m}$ and $R_{z}=1000 \mathrm{~m}$ for the vertical sections. Horizontal straight lines indicate the positions of the vertical and horizontal cross-sections. In ( $a, b, c, d)$, the diagonal black lines indicate the orientation of observed convergence lines. (i, j, k, l) show satellite visible cloud images at 1500, 1530, 1630 and 1645 UTC respectively, with the square indicating the scan volume $(100 \mathrm{~km} \times 100 \mathrm{~km})$ of the MIT radar.

properties of gust fronts and their interactions with the ambient air have been studied using tower data (Charba, 1974; Goff, 1976), Doppler radar data (Wakimoto, 1982; Wilson and Schreiber, 1986), and wind profilers with the radio acoustic sounding system (RASS; May, 1999). Benjamin (1968) and Simpson and Britter (1980) defined gust fronts as examples of gravity currents. Wilson and Schreiber (1986) and Lima and Wilson (2008) found that gust fronts were most often associated with deep convection.

Gust fronts are observed in the reflectivity radar fields after they move away from the deep convective cell that generated them and they form a thin line of echo in the lower troposphere. Zrnić and Lee (1983) used the $2 \mathrm{dBZ}$ contour to define the gust front echo. Diana and Smith
(1987) found that, for the nine cases of gust fronts studied, the reflectivity remained smaller than $7 \mathrm{dBZ}$ within the gust front. Horizontal cross-sections of reflectivity radar at low levels $(300-600 \mathrm{~m})$ are used here to observe the formation and propagation of the gust fronts in the volume scanned by the MIT radar, combined with pressure rise, wind shift, wind surge, and temperature drop deduced from the meteorological stations around Niamey, when appropriate (not shown). The height of the density current was delimited by the vertical cross-section of reflectivity.

Figure 6 shows the reflectivity interpolated in horizontal cross-sections at $300 \mathrm{~m}$ height and vertical zonal crosssections $15 \mathrm{~km}$ to the south of the MIT radar, at 1610, 1640 and 1730 UTC on 11 July 2006. The first deep convective 

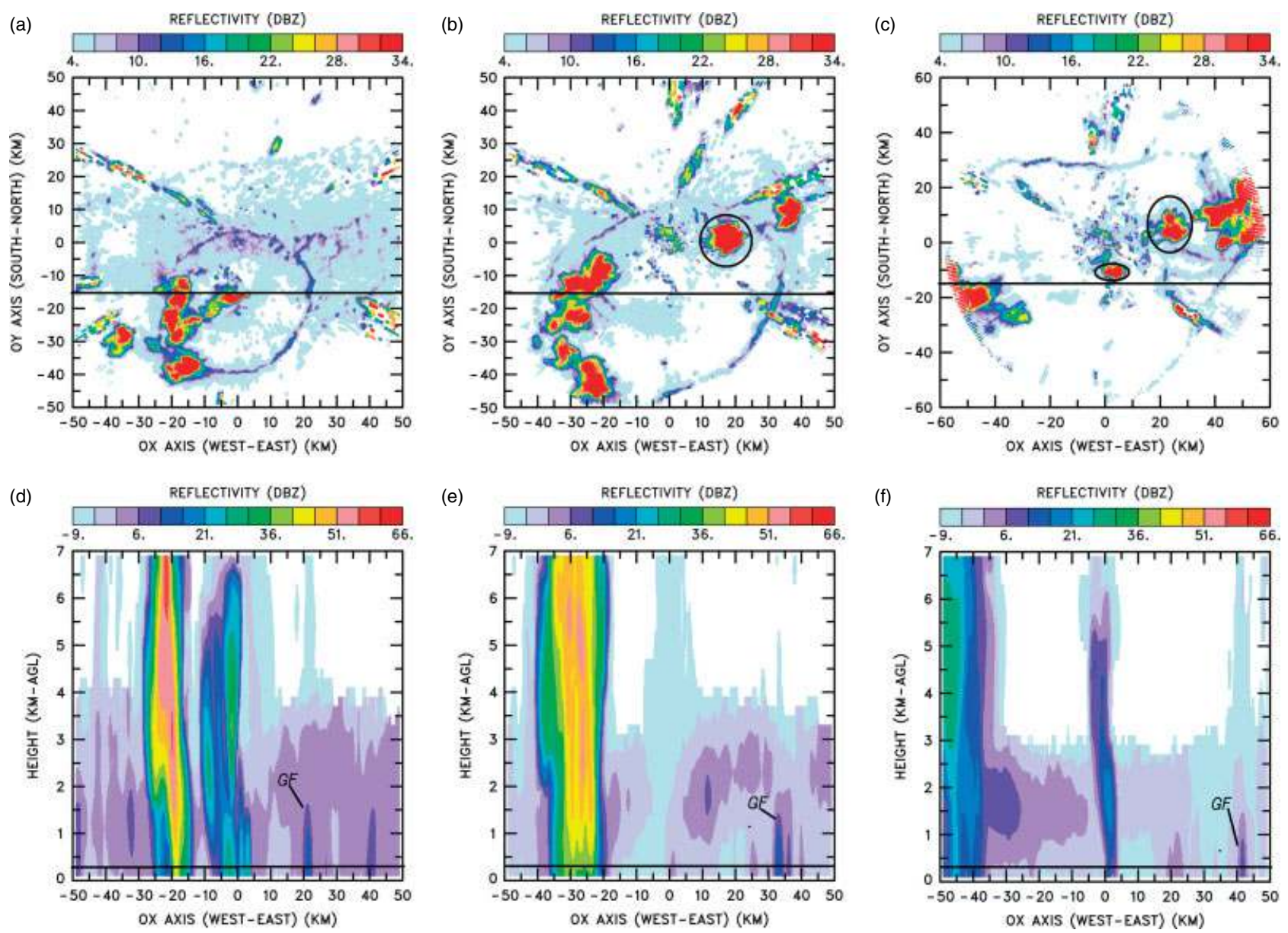

Figure 6. Reflectivity interpolated onto (a, b, c) horizontal cross-sections at $Z=300 \mathrm{~m}$ agl, and (d, e, $\mathrm{f}$ ) vertical cross-sections at $Y=-15 \mathrm{~km}$, at (a, d) 1610 UTC, (b, e) 1640 UTC, and (c, f) 1730 UTC on 11 July 2006. The MIT radar was positioned at the reference point $(X=0, Y=0)$. Here $R_{x y}=600 \mathrm{~m}$ and $R_{z}=350 \mathrm{~m}$ are used for interpolation on the horizontal sections and $R_{x y}=1000 \mathrm{~m}$ and $R_{z}=1000 \mathrm{~m}$ for the vertical sections. Cells triggered by the gust front are circled in black. 'GF' indicates the top of the gust front. In (a, b, c) a minimum radar reflectivity of $4 \mathrm{dBZ}$ on the colourscale is used to mask the clear air organisation and to point out the clear signature of the gust front.

cell developed at 1510 UTC, $20 \mathrm{~km}$ to the south of the MIT radar $(X=0 \mathrm{~km}, Y=-20 \mathrm{~km}$, not shown). It propagated southwestward, became very deep and generated a circular gust front at 1610 UTC (Figure 6(a)). We found reflectivities generally around $11 \mathrm{dBZ}$ in the gust front, and sometimes larger than $15 \mathrm{dBZ}$, which is greater than observed by Diana and Smith (1987). New deep convective cells (up to $1500 \mathrm{~m}$ in places) were observed a few minutes later in the volume swept by the density current. They propagated in the same direction as the first deep cell but dissipated shortly afterwards (Figure 6(b, c)). This case was very similar to the case studied by Lothon et al. (2011) (10 July, also included here), in which the gust front initiated several other convective cells with a life span of less than $2 \mathrm{~h}$. In addition to 10 and 11 July, we found five other days among the nine cases of class LC in which gust fronts generated new convective cells. On only one day was a gust front observed which did not generate new deep convective cells (8 July 2006).

\subsection{Atmospheric CBL structure}

The atmospheric CBL structure can be organised into rolls or cells depending, among other factors, on instability. LeMone (1973), Grossman (1982) and Weckwerth et al. (1997) found that the conditions for the development and maintenance of rolls are a positive surface heat flux, some minimal low-level wind shear, and a uniform surface. Rolls influence the formation and structure of boundarylayer clouds (Huang et al., 2009) and can promote deep convection by modifying the water vapour distribution (Weckwerth, 2000). Wilde et al. (1985) showed that rolls are often topped by cumulus clouds atop their updraught branches (e.g. Kuettner, 1959, 1971; LeMone and Pennell, 1976; Christian and Wakimoto, 1989). Wilson et al. (1992) showed that the intersection between convergence zones and horizontal convective rolls was a favourable zone for convective development. Using large-eddy simulations, Huang et al. (2009) compared deepening of shallow cumuli as a function of the type of organisation within the CBL. They found only a weak preferential deepening of cells relative to rolls.

Due to the potential importance of the rolls in deep convection triggering, we analysed the organisation of the $\mathrm{CBL}$ prior to the triggering of deep convection, using the horizontal cross-sections of the MIT radar reflectivity at low levels (Christian and Wakimoto, 1989). We defined roll convective structures based on the following criteria: an alignment of structures of local reflectivity maximum longer than $10 \mathrm{~km}$ (one band-like structure being at least 2 or $3 \mathrm{~km}$ long within this line), and at least three parallel and successive such bands in the considered area. 
Table 2 shows that the development of boundary-layer rolls started in the early morning for all but one case of class LC (27 July 2006). The rolls evolved into thermal cells in the early afternoon for all cases of this class. The same organisation was observed for classes $\mathrm{SH}$ and FW with about the same timing (Tables 3 and 4). Rolls evolved into thermal cells in the early afternoon around 1300 UTC for cases SH and FW, as for cases LC. By contrast, thermal cells or heterogeneous organisations were observed for class PC, after the passage of the MCS. On three PC days, thermal cells developed in the early morning and further evolved into rolls in the early afternoon, while on two other PC days only thermal cells were observed in the afternoon (Table 5). After the MCSs crossed the area, the cloud cover usually remained high for several hours; cells prevented surface heating, and consequently inhibited the growth of the CBL.

Table 2 thus shows that the early morning dominant organisation in the CBL is rolls for all days except one in classes FW, SH and LC. Note that most of the time, rolls observed with the MIT radar are not associated with clouds (especially in the morning).

Previous studies of the CBL organisation showed that the instability ratio $-Z_{\mathrm{i}} / L$ can be related to the observed type of structures. For example, Weckwerth (1995) and Weckwerth et al. (1997) found a threshold of 25 for this index, above which mainly thermal cells are observed, while rolls are found for $-Z_{\mathrm{i}} / L<25$. Huang et al. (2009) pointed to a more subtle dependence on $-Z_{i} / L$; they found that the $-Z_{\mathrm{i}} / L$ threshold for the transition from rolls to cells was a function of a non-dimensional combination of the low-level wind shear, the height of the CBL, and the eddy velocity scale.

In our study, for class LC (Table 2 ), the ratio $-Z_{\mathrm{i}} / L$ varied between 10 and 194 at the beginning of the organisation of rolls. This is consistent with Ferrare et al. (1991), whose $-Z_{\mathrm{i}} / L$ values varied between 25 and 250 for a boundary-layer height between 100 and $1300 \mathrm{~m}$. Christian and Wakimoto (1989) also found larger values of $-Z_{\mathrm{i}} / L$ for a case-study.

The instability for some cases was very strong, yet rolls still persisted for those cases. In the afternoon, when the rolls turned to thermal cells for this class, the ratio $-Z_{\mathrm{i}} / L$ increased for all cases and varied between 83 and 364. The increase of instability in the afternoon favoured local deep convection. For class $\mathrm{SH}$ (Table 3 ), the ratio $-Z_{\mathrm{i}} / L$ and $Z_{\mathrm{i}}$ were similar to those of class LC at the beginning of the rolls organisation, but when they evolved into thermal cells $-Z_{\mathrm{i}} / L$ was lower than those of $L C$ and varied between 67 and 99. For class $\mathrm{FW},-Z_{\mathrm{i}} / L$ and $Z_{\mathrm{i}}$ were generally lower than those of LC and SH (Table 4). For all LC, SH and FW cases, the low-level wind shear was weak, with values between $1.8 \times 10^{-3}$ and $5.5 \times 10^{-3} \mathrm{~s}^{-1}$ (Tables 2 to 4 ). This would favour the transition to cells, as well as the large sensible heat flux observed. Huang et al. (2009) found that rolls persisted for surface buoyancy fluxes less than $110 \mathrm{~W} \mathrm{~m}^{-2}$, and formed for boundary-layer wind shears greater than $5 \times 10^{-3} \mathrm{~s}^{-1}$. Our observations contrast with those previous results and reveal a persistence of rolls in conditions of low shear, large sensible heat flux, and large instability. Note, however, that our calculation of $Z_{\mathrm{i}}$ and $L$ was made at only one location at the centre of the study area, and may not be representative of the entire study area. Furthermore, we did not find an obvious contribution of the combination of $Z_{i}$, wind shear and velocity convective scale to the transition as suggested by Huang et al. (2009).
Class PC has the lowest $-Z_{\mathrm{i}} / L$ and $Z_{\mathrm{i}}$ due to the impact of the passage of the MCS, and the residual cells are heterogeneous. For this class, rolls may form in the early afternoon and do not turn into thermal cells (Table 5).

\section{Analysis of the triggering factors of deep convection, and characterisation of the convection classes}

In this section, we analyse the triggering factors which may differentiate convection classes observed over Niamey. For this, a composite approach can be used for each class of convection; an average of some key variables over all cases of each class is made. The variability among cases is also discussed.

\subsection{Atmospheric stability parameters}

The CAPE and CIN were calculated from parcel calculations using the average virtual potential temperature over the lowest $100 \mathrm{hPa}$ (Doswell and Rasmussen, 1994). We consider two different times for which radiosonde profiles are available before the afternoon convection: 0530 and 1130 UTC. The first is a broadly used time for operational radiosonde networks, reanalyses and forecasts, which led us to choose this time to identify the factors which distinguish the convection classes and predict the afternoon convection. The second time provides a better opportunity for doing so, as the CBL has developed by then and the conditions approach the time of triggering. Figure 7 represents the CIN as a function of the CAPE at 0530 and 1130 UTC for all cases of convection days.

At 0530 UTC, it is very difficult to predict the afternoon local deep convection, since all cases from various classes have values of CAPE and CIN which spread over a large range. Many cases of any class have CAPE $>500 \mathrm{~J} \mathrm{~kg}^{-1}$, but $\mathrm{CIN}<-200 \mathrm{~J} \mathrm{~kg}^{-1}$, which is unfavourable for deep convection (Figure 7(a)). The high values of CAPE for class $\mathrm{PC}$ are due to the instability of the atmosphere before the passage of the MCSs (Table 5). The deep convection usually initiated in the late afternoon to the east of Niamey and propagates westward, passing through the volume scan of the MIT radar at night or early morning.

At 1130 UTC (Figure 7(b)), classes PC and FW have $\mathrm{CAPE}<500 \mathrm{~J} \mathrm{~kg}^{-1}$ and $\mathrm{CIN}<-200 \mathrm{~J} \mathrm{~kg}^{-1}$, unfavourable to deep convection. The conditions start to become favourable for most cases of classes LC and $\mathrm{SH}$ with larger CAPE $\left(\mathrm{CAPE}>600 \mathrm{~J} \mathrm{~kg}^{-1}\right)$ and $-200<\mathrm{CIN}<0 \mathrm{~J} \mathrm{~kg}^{-1}$. There is a very high value of CAPE over $6000 \mathrm{~J} \mathrm{~kg}^{-1}$ (not shown in Figure 7) for only one case of afternoon local deep convection (28 July 2006). Thus, at this time of day, we may separate (LC, SH) from (PC, FW), but it is still difficult to distinguish shallow convection days from afternoon local deep convection days.

Note that we found results similar to those found at 1130 UTC when considering a time closer to the initiation of deep convection, around 1500 UTC, and interpolating the profiles at 1500 UTC based on the 1130 and 1730 UTC soundings. Beyond some obvious limitations, this provided a rough idea of the mean vertical structure before triggering. Also, considering other indexes like the lifting index and $\mathrm{K}$-index rather than the CIN led to the same conclusions.

Between 0530 and 1130 UTC, the CAPE of PC cases decreases significantly. For the FW cases the decrease in CIN is larger than the change in CAPE. Classes LC and SH have 

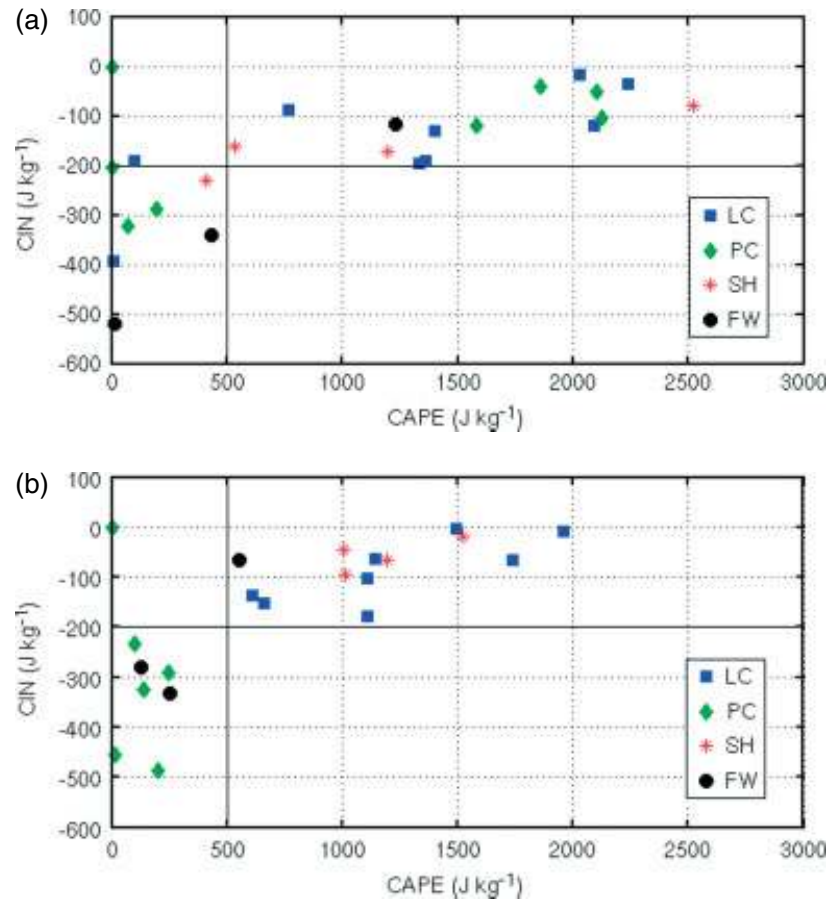

Figure 7. CIN as a function of CAPE at (a) 0530 UTC and (b) 1130 UTC for all days from 6 to 31 July 2006. LC are cases of locally initiated deep convection, PC cases of propagating deep convection, $\mathrm{SH}$ cases of shallow convection and FW cases of fair weather. Note that the radiosonde on 28 July at 1130 UTC is erroneous, and is not shown here.

a significant decrease of CIN (with CBL mixing) and often a decrease of CAPE (Figure 7).

By using the convective triggering potential (CTP) and a humidity index $H I_{\text {low }}$, Findell and Eltahir (2003) evaluated the chance of deep convection occurrence over dry or wet soil in Illinois. They found that

(i) for $H I_{\text {low }}>15^{\circ} \mathrm{C}$, the atmosphere is very dry and stable when $\mathrm{CTP}<0 \mathrm{~J} \mathrm{~kg}^{-1}$, and rainfall cannot occur independently of flux partitioning at the surface;

(ii) for $H I_{\text {low }}<5{ }^{\circ} \mathrm{C}$ and $\mathrm{CTP}>0 \mathrm{~J} \mathrm{~kg}^{-1}$, rainfall should occur over both wet and dry soils;

(iii) for $\mathrm{HI}_{\mathrm{low}}$ between 5 and $15^{\circ} \mathrm{C}$ and $\mathrm{CTP}>0 \mathrm{~J} \mathrm{~kg}^{-1}$, dry soils are more likely to trigger rainfall with high CTP and $H I_{\text {low }}$, and wet soils are more likely with low CTP and $H I_{\text {low }}$.

Here we try to classify the types of convection using this theory, noting that the surface is generally dry during the study period. Based on these indexes, CTP and $\mathrm{HI}_{\text {low }}$ were estimated using the radiosonde data. Figure 8 represents the evolution of $H I_{\text {low }}$ as a function of CTP for all classes of convection at 0530 UTC. It shows that at this time, it is very difficult to distinguish the convection classes and the regimes proposed by Findell and Eltahir (2003). For $\mathrm{CTP}<0 \mathrm{~J} \mathrm{~kg}^{-1}$, only one example of LC and PC is observed, for $H I_{\text {low }}<5^{\circ} \mathrm{C}$ and CTP $>0 \mathrm{~J} \mathrm{~kg}^{-1}$ two cases of PC and LC are found, for $H I_{\text {low }}$ between 5 and $15^{\circ} \mathrm{C}$ and $\mathrm{CTP}>0 \mathrm{~J} \mathrm{~kg}^{-1}$ all cases of $\mathrm{SH}$, two cases of $\mathrm{FW}$, two cases of $\mathrm{LC}$ and four cases of PC were observed. For $H I_{\text {low }}$ between 15 and $25^{\circ} \mathrm{C}$, four cases of LC, one case of FW and two cases of PC were found. The CTP and $\mathrm{HI}_{\text {low }}$ found at this time can be influenced for class PC by the passage of deep convection before the considered time (Table 5) by increasing the CTP or decreasing the $H I_{\text {low }}$. The other classes (FW, SH,

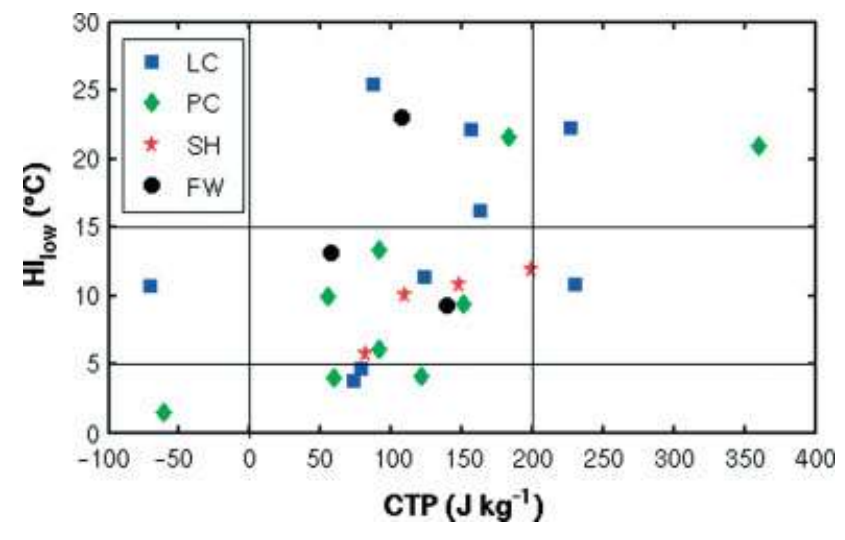

Figure 8. CTP and $\mathrm{HI}_{\text {low }}$ at 0530 UTC. Classes are as in Figure 7.

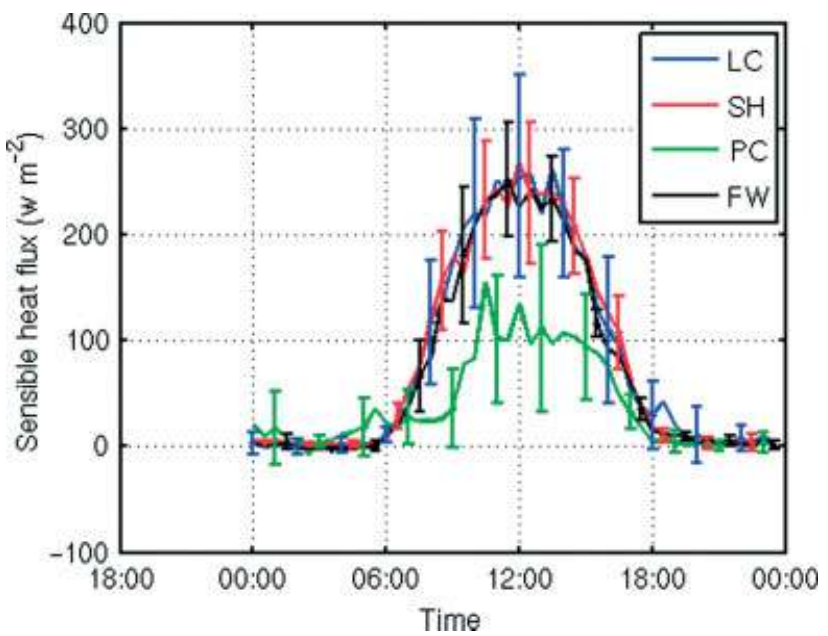

Figure 9. Composite diurnal cycle of sensible heat flux from the surface flux data at Niamey Airport, for each class. Error bars represent the standard deviation over the cases in the class.

and LC) can be influenced by the SAL, leading to large $H I_{\text {low }}$.

We conclude that it is very difficult to predict the type of convection which will be formed during the day, based on the CTP and $H I_{\text {low }}$ indexes.

\subsection{Surface turbulence fluxes}

Surface heat fluxes are important quantities in land surface-atmosphere interaction since they transfer the heat of the solar radiation from the surface to the atmosphere. Using numerical simulations of the case of 10 July 2006, Couvreux et al. (2012) pointed out the key role played by the sensible heat flux in initiating deep convection in semiarid conditions. No deep convection occurred in simulations which did not have sufficient surface buoyancy flux. Figure 9 shows the composite diurnal cycle of surface sensible heat flux for the four classes PC, FW, SH, and LC. For each time, an average is made over the cases of a given class. Classes SH, FW, and LC have the same evolution of the diurnal cycle of sensible heat flux at all times. Figure 9 shows that the surface fluxes cannot distinguish the shallow convection from the locally initiated deep convection or fair weather. On propagating convection days, the sensible heat flux is much smaller than those of other classes, but this reflects the passage of the MCSs the morning or night before. 

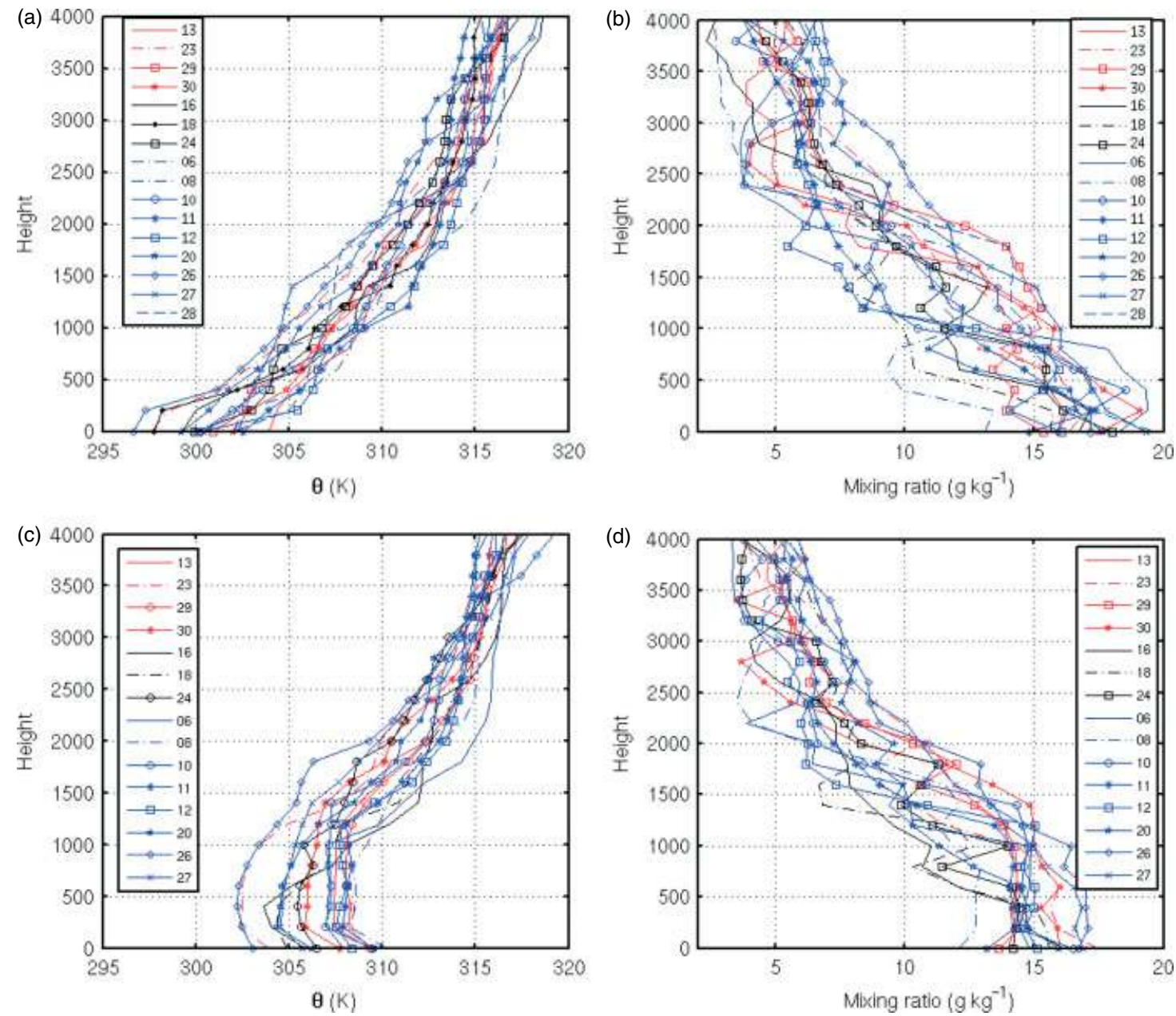

Figure 10. Vertical profiles of (a, c) potential temperature $\theta$ and (b, d) mixing ratio at (a, b) 0530 UTC and (c, d) 1130 UTC on each day with the assigned class shown: shallow convection (red), fair weather (black) and locally initiated deep convection (blue).

Given the spatial heterogeneity of surface fluxes at this period, data from a single station may not be fully representative of the whole mesoscale area under study. However, the three classes FW, SH and LC reveal large surface buoyancy fluxes.

\subsection{Growth of the CBL}

Using the HAPEX-Sahel dataset, Wai et al. (1997) found that the boundary layer responds quickly to the transition from wet to dry seasons; this was also observed by Gounou et al. (2012) for the onset period. Kohler et al. (2010) found that the diurnal development of convective instability was dominated by the CBL evolution and controlled by the transfers in the mid or upper troposphere. The diurnal cycle of the surface heat fluxes drives the growth of the atmospheric boundary layer. In this section, we analyse the processes at the low level, from the surface to $4 \mathrm{~km}$ above.

Figure 10 shows the vertical profiles in the low levels for potential temperature $\theta$ and water vapour mixing ratio at 0530 and 1130 UTC for classes SH, FW, and LC.

At 0530 UTC the vertical profiles of $\theta$ are quite similar in the three classes of convection. They are characterised by a cool stable layer at the low levels. However, the inversion layer is generally larger in fair weather cases than in shallow convection cases; a wet nocturnal surface layer with mixing ratio greater than $15 \mathrm{~g} \mathrm{~kg}^{-1}$ is observed for all cases of the three classes due to the occurrence of the nocturnal low-level jet. Cases of class FW often have a smaller mixing ratio than those of class $\mathrm{SH}$ in the lower troposphere.

Through the heating of the surface, there is a significant transformation of air mass between 0530 and 1130 UTC (Figure 10(c, d)). At 1130 UTC the mixed layer differs from one class of convection to the other. Cases of FW have cooler and thinner CBLs than those of classes SH and LC. The mixed layer of SH cases all have deeper CBLs, with $Z_{\mathrm{i}}$ greater than $1200 \mathrm{~m}$ (Figure 10(c)). The low troposphere is drier for the FW cases at that time, as observed at 0530 UTC. This dry air noted at the low levels for FW is unfavourable for the formation of cumulus cloud at the top of the boundary layer, because the level of condensation of the air mass is then higher than the CBL top attained.

Note that the moisture supplied by the nocturnal jet is distributed in the boundary layer by the diurnal convection for classes SH and LC, and to a lesser extent for class FW. Between 0530 and 1130 UTC, LC cases show a wet and deep mixed layer.

Figure 11 shows the composite diurnal cycle of the CBL depth for all convection classes, based on the estimates of $Z_{\mathrm{i}}$ by the UHF wind profiler. On propagating deep convection days, the CBL height grows slowly before reaching about $1 \mathrm{~km}$ in the late afternoon. On fair weather days, the CBL height grows moderately and reaches around $1.5 \mathrm{~km}$ after 1530 UTC, and continues to rise. On shallow convection and afternoon local deep convection days, the CBL height 


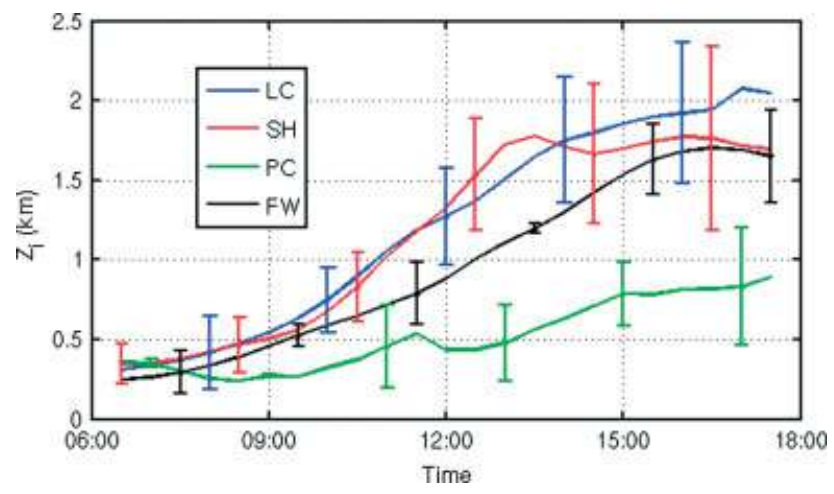

Figure 11. Composite diurnal cycle of the CBL height for each class deduced from the UHF wind profiler: afternoon local deep convection days (blue), shallow convection days (red), propagating deep convection days (green) and fair weather days (black). We considered that the boundarylayer depth is not defined during a rainfall event.

grows more rapidly. However, the CBL height continues to grow between 1300 and 1800 UTC for class LC, while $Z_{\mathrm{i}}$ tends to level off for SH cases.

Thus, the LC and $\mathrm{SH}$ classes are distinguished from FW and PC classes by a deeper and faster-growing CBL.

\subsection{Divergence}

The divergence profile determines the type of stability of the atmosphere. It allows us to define the rates at which the boundary layer would become shallower or deeper in the absence of entrainment (intrusion of free trosposphere air into the $\mathrm{CBL}$ ). Divergence has an important influence on the formation and development of the atmospheric boundarylayer clouds. Small divergence can allow the atmospheric boundary layer to grow sufficiently and approach the level of free convection (LFC), while a large divergence may lower the atmospheric boundary-layer height below the LFC or prevent clouds from developing.

Figure 12 shows the vertical profiles (as a function of normalized height $Z / Z_{\mathrm{i}}$ ) of horizontal divergence deduced from the MIT Doppler velocity with the VVP method described in section 2.1. These profiles are an average of the profiles of estimated divergence between 1100 and 1500 UTC every day and for cases in the classes LC, SH and FW, i.e. prior to the triggering of deep convective cells. Here we consider only LC cases for which the deep convective cells were initiated within the $30 \mathrm{~km}$ radius of the VVP analysis. Thus, the cases of 6, 8, 20 and 26 July 2006 are discarded. The errorbars in Figure 12 indicate the VVP statistical error (standard deviation), which is $0.03 \times 10^{-4} \mathrm{~s}^{-1}$ on average over the studied period.

On shallow convection and fair weather days, the flow is found to be convergent at the low levels (mixed layer), but divergent above, close to the entrainment zone. Classes $\mathrm{SH}$ and FW have larger convergence at low levels than LC but divergence above. All cases of class SH (Figure 12(b)) have especially significant divergence which may block further development of boundary-layer clouds (cumulus). The divergence observed around the boundary-layer top reduces the growth of the atmospheric boundary layer (section 4.3).

The case of 26 July 2006 (not shown) shows strong divergence, indicating subsidence of the air flow due to the passage of the MCS. On propagating deep convection days
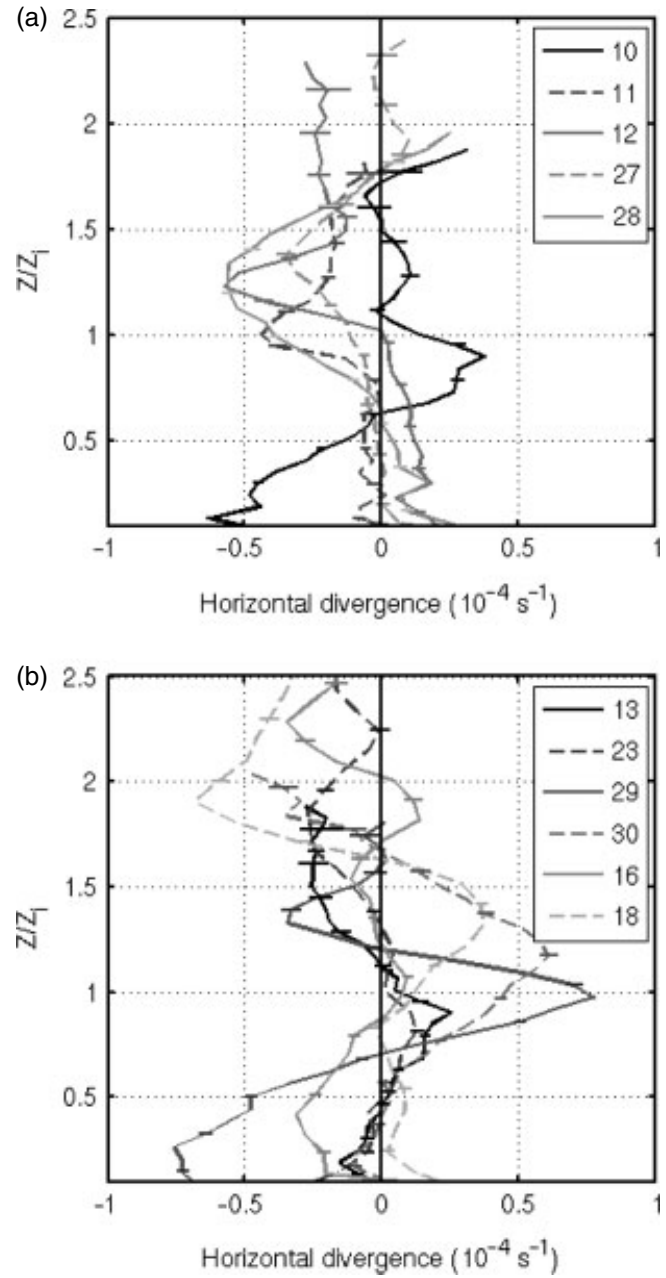

Figure 12. Horizontal divergence averaged between 1100 and 1500 UTC as a function of normalised height: (a) afternoon local deep convection days, (b) shallow convection days (13, 23, 29, and 30) and fair weather days (16 and 18).

(not shown), the flow is found to be divergent at low levels from the surface up to $1.6 \mathrm{~km}$ height and convergent above.

Thus, we confirm that a convergence flow in the layer between the boundary-layer top and the free troposphere is necessary in order to distinguish afternoon local deep convection from other convection cases. This result is consistent with Xin and Reuter (1998), who found using the VVP method that the initiation and enhancement of precipitating cells are associated with low-level convergence. It is also in line with Couvreux et al. (2012) simulations, which were not able to trigger deep convection without adding some large-scale updraught at the low levels. Here, it appears that the transition from shallow convection to deep convection is associated with enhanced convergence above the atmospheric boundary-layer top.

\section{Summary and conclusions}

The MIT radar data for the 2006 AMMA campaign combined with data from satellites, $95 \mathrm{GHz}$ cloud radar, radiosondes, and UHF wind profiler have been used to characterise the diurnal cycle into different atmospheric convection regimes in the Sahel over Niamey. This study is based on the analysis of horizontal and vertical crosssections of reflectivity of the MIT radar in the scanned 
volume $(100 \mathrm{~km} \times 100 \mathrm{~km}$ centred on the position of the radar) and confirmed by the satellite data in the same area for 26 days of July 2006. Four types of convection regimes were identified: fair weather (FW) with a clear sky all day (three cases), ( $\mathrm{SH}$ ) shallow convection (four cases), (LC) afternoon locally initiated deep convection (nine cases) and (PC) propagating deep convection (ten cases). We found a large occurrence of locally initiated deep convection during this period, as large as that of propagating MCSs passing through the area.

In the early morning, the boundary-layer convective structures are organised in rolls or bands for all cases except one in classes SH, FW and LC. Residual cells or heterogeneous convective structures are observed for the propagating convection days and, for this class, the rolls form in the afternoon. The ratio $-Z_{\mathrm{i}} / L$ depends on the atmospheric conditions; at the beginning of the roll organisation, it is greater than 10 and sometimes reaches values higher than 100 . Rolls turn to cells when $-Z_{\mathrm{i}} / L$ and $-Z_{i}$ become large enough to show a strong instability in the boundary layer in the early afternoon but, contrary to previous studies, rolls persist with quite large $-Z_{\mathrm{i}} / L$ in our study.

The capability of the MIT radar to observe the gust fronts and convection lines was demonstrated. The data suggested the important role of the convergence line as a precursor of afternoon locally initiated deep convection in the Sahel. We found three days with occurrences of convergence lines around Niamey during the study period, over the nine days of LC. Most of the cases of local deep convection were associated with gust fronts which triggered new cells in the area swept by the density current.

The analysis of the atmospheric instability factors (CAPE, CIN, CTP and $H I_{\text {low }}$ ) shows the difficulties associated with predicting deep convection occurrence with those parameters alone. Even at 1130 UTC, CAPE and CIN helped to predict the convection but did not separate classes of local deep convection from shallow convection. CTP and $H I_{\text {low }}$ also vary for all classes at this time.

Classes FW, SH and LC show several similar conditions that are favourable for deep convection, but FW has smaller convective boundary layer $(\mathrm{CBL})$ growth relative to the two other classes. The CBL is also cooler and drier than for SH and LC cases. LC cases have the deepest, warmest and wettest CBLs. SH and LC cases are distinguished only by the existence of a significant divergence above the CBL for class SH, while convergence is observed for LC. FW cases also show divergence above the CBL, but less than for class $\mathrm{SH}$. The three classes FW, SH and LC have convergence in the lowest troposphere. In PC cases, the low atmosphere is marked by the passage of the propagating MCS, and is very different from the three other classes: dry and cool atmosphere, small CBL depth, and divergence in the low troposphere.

Some large-scale situations also favour the transition from shallow to deep convection, given similar local factors like surface buoyancy flux and CBL dynamics. The role of largescale dynamics remains to be investigated. Additionally, the role of the surface temperature and moisture heterogeneity requires further analysis. This was addressed in a case study by Lothon et al. (2011), along with the capacity of gust fronts to trigger new cells. We have observed that, for many of the LC cases considered here and in agreement with Taylor et al. (2011), the deep convective cells were initiated on a warm surface relative to their mesoscale surroundings (not shown). We also observed that many of the deep convective cells generated a gust front, and that most of these trigger new convective cells.

Future work will consider the same set of cases to further analyse the role of the surface heterogeneity and the capacity of the gust fronts to trigger deep convection at favoured locations.

\section{Appendix}

\section{Velocity volume processing (VVP) analysis}

The series of conical scans with increasing elevation enables us to estimate the dynamical characteristics of the mean flow as a function of height through use of the Velocity Volume Processing (VVP) technique (Waldteufel and Corbin, 1979). This technique is based on the hypothesis of local linearity of the mean wind field parameters within elementary cylindrical slices. In each slice, several thousand data points are involved in the calculation of the wind field parameters. The VVP analysis thus retrieves vertical profiles of the horizontal mean velocity components, vertical wind shear, and divergence. The parameters provided by the VVP method are representative of atmospheric scales greater than or equal to the size of the cylindrical slices. The VVP method has been applied to studies of the low-level kinematic wind field in clear air (Koscielny et al., 1982; Boccippio, 1995) and to the study of thunderstorm anvils (Boccippio, 1995). Here, we use this VVP analysis to estimate horizontal divergence. The statistical error associated with such estimates depends on the number of data points, their spatial distribution, and the departure of the wind field from linearity. The characteristics of the elementary slices are chosen to optimize the quality of the retrieval, i.e. a compromise between a good vertical resolution and a reduced statistical error. Considering the geometry of the radar data, a $100 \mathrm{~m}$ vertical depth and a $30 \mathrm{~km}$ horizontal radius were chosen for the VVP. For the vertical profiles of divergence, the VVP statistical error is around $0.03 \times 10^{-4} \mathrm{~s}^{-1}$.

We also considered a possible bias on the divergence measurement due to an incorrect orientation of the antenna axis affecting the elevation angles. If this happens, a measurement gate at a fixed radial distance during an azimuth scan will describe a circle in a slant plane rather than a horizontal plane. As a consequence, horizontal derivatives retrieved in these non-horizontal surfaces encompass part of the vertical variation of the wind. It is relatively easy to check for the existence of this source of bias because we expect a strong correlation between the pseudo-horizontal derivatives and the components of the vertical wind shear. We selected observations collected during the low-level nocturnal jet and in the AEJ, which both generate significant wind shear. We rotated the horizontal frame $X \circ Y$ until we obtain the maximum correlation of one of the horizontal derivatives (also the minimum for the other). The linear correlation coefficient between the horizontal derivative and the corresponding vertical derivative reached more than 0.8 in the nocturnal jet. This correlation allowed us to derive the azimuth direction of the slope of the slant plane $\left(25^{\circ}\right)$ and the slope angle relative to the horizontal $\left(0.3 \pm 0.2^{\circ}\right)$. We obtained nearly the same values for different nights. With these parameters it was possible to correct the measurement of the horizontal derivatives. The correction 
(of the order of $10^{-4} \mathrm{~s}^{-1}$ ) showed the same magnitude as the horizontal derivatives but the corrected vertical profiles followed nearly the same vertical trend as without correction. However, when expecting to obtain the same parameter values in the AEJ, we obtained a value less than 0.2 for the correlation coefficient, a slope angle around $0.1^{\circ}$ and an azimuth angle strongly variable across the considered days. We concluded that the bias on the horizontal divergence resulting from an antenna axis pointing in an incorrect direction was not conclusive and was certainly weak, and that the strong correlation between horizontal derivatives and vertical derivatives in the low-level jet was not an artefact but a natural consequence of this particular circulation.

\section{Acknowledgements}

The Laboratoire d'Aérologie is funded by INSU-CNRS and the University of Toulouse. Based on a French initiative, AMMA was built by an international scientific group and is currently funded by a large number of agencies, especially from France, the UK, the USA, and Africa. It has been the beneficiary of a major financial contribution from the European Community's Sixth Framework Research Program. (Detailed information on scientific coordination and funding is available on the AMMA International Web site at http://www.amma-international.org) The authors also thank the Massachusetts Institute of Technology and NASA Hydrology for supporting the operation of the radar in Niamey. We thank Brian Russell for his organisation and archival of the MIT radar data. We thank the Atmospheric Radiation Measurement Facility for operating the UHF wind profiler, radiosonde data and surface stations, and for supplying the data. The primary author of this article thanks the SCAC (Service de Coopération et d'Action Culturelle) of the French embassy in Dakar for scholarship support and the PCSI (Programme de Coopération Scientifique Inter-universitaire) programme supported by AUF (Agence Universitaire de la Francophonie) for funding a three-month internship in France and the QWeCI (Quantifying Weather and Climate Impacts on Health in Developing Countries) project. The authors appreciated the comments from two anonymous reviewers and from the Editor, which helped to substantially improve the manuscript. We thank Salack Seyni and Debra Bellon for proofreading this article.

\section{References}

Angevine WM, White AB, Avery SK. 1994. Boundary-layer depth and entrainment zone characterization with a boundary-layer profiler. Boundary-Layer Meteorol. 68: 375-385.

Balsley BB, Gage KS. 1982. On the use of radars for operational wind profiling. Bull. Amer. Meteorol. Soc. 63: 1009-1018.

Bart JJ, Van Den Hurk M, Van Meijgaard E. 2010. Diagnosing land-atmosphere interaction from a regional climate model simulation over West Africa. J. Hydrometeorol. 11: 467-481.

Barthe C, Asencio N, Lafore JP, Chong M, Campistron B, Cazenave F. 2010. Multi-scale analysis of the 25-27 July 2006 convective period over Niamey: Comparison between Doppler radar observations and simulations. Q. J. R. Meteorol. Soc. 136: 190-208.

Benjamin TB. 1968. Gravity currents and related phenomena. J. Fluid. Mech. 31: 209-248.

Bocciopio DJ. 1995. A diagnostic analysis of VVP single-Doppler radar retrieval technique. J. Atmos. Oceanic Technol. 12: 230-248.

Bouniol D, Couvreux F, Kamsu-Tamo PH, Lepay M, Guichard F, Favot F. 2012. Diurnal and seasonal cycles of cloud occurrences, types, and radiative impact over West Africa. J. Appl. Meteorol. Climatol. 51: $534-553$.
Byers HR, Braham RR. 1949. The Thunderstorm. US Govt. Printing Office: Washington DC.

Charba J. 1974. Application of gravity current model to analysis of squall line gust front. Mon. Weather Rev. 102: 140-156.

Christian TW, Wakimoto RM. 1989. The relationship between radar reflectivities and clouds associated with horizontal roll convection on 8 August 1982. Mon. Weather Rev. 117: 1530-1544.

Comer RE, Slingo A, Allan RP. 2007. Observations of the diurnal cycle of outgoing longwave radiation from the Geostationary Earth Radiation Budget instrument. Geophys. Res. Lett. 34: L02823, DOI: 10.1029/2006GL028229.

Couvreux F, Rio C, Guichard F, Lothon M, Canut G, Bouniol D, Gounou A. 2012. Initiation of daytime local convection in a semiarid region analyzed with high-resolution simulations and AMMA observations. Q. J. R. Meteorol. Soc. 138: 56-71.

Cressman GW. 1959. An operational objective analysis system. Mon. Weather Rev. 87: 367-374.

Diana LK, Smith DR. 1987. Gust fronts as detected by Doppler radar. Mon. Weather Rev. 115: 905-917.

Doswell CA III, Rasmussen EN. 1994. The effect of neglecting the virtual temperature correction on CAPE calculations. Weather Forecasting 2 : 625-629.

Doviak RJ, Zrnić DS. 1993. Doppler Radar and Weather Observations. 2nd ed. Academic Press: Singapore.

D'Amato N, Lebel T. 1998. On the characteristics of the rainfall events in the Sahel with a view to the analysis of climatic variability. Internat. J. Climatol. 18: 955-974.

Fabry F. 2005. The spatial variability of moisture in the boundary layer and its effect on convection initiation: Projet-long characterization. Mon. Weather Rev. 134: 79-91.

Ferrare RA, Schols JL, Eloranta EW. 1991. Lidar observations of banded convection during BLX83. J. Appl. Meteorol. 30: 312-326.

Findell KL, Eltahir AB. 2003. Atmospheric controls on soil moisture-boundary layer interactions. Part I : Framework development. J. Hydrometeorol. 4: 552-569.

Garcia-Carreras L, Parker D, Marsham JH. 2011. What is the mechanism for the modification of convection cloud distributions by land surfaceinduced flows? J. Atmos. Sci. 68: 619-634.

Goff CR. 1976. Vertical structure of thunderstorm outflows. Mon. Weather Rev. 104: 1429-1440.

Gossard EE, Chadwick RB, Neff WD, Moran KP. 1982. The use of ground-based Doppler radars to measure gradients, fluxes, and structure parameters in elevated layers. J. Appl. Meteorol. 21:211-226.

Gounou A, Guichard F, Couvreux F. 2012. Observations of diurnal cycles over a West African meridional transect: Pre-monsoon and full-monsoon seasons. Boundary-Layer Meteorol. 144: 329-357. DOI: 10.1007/s10546-012-9723-8.

Grossman RL. 1982. An analysis of vertical velocity spectra obtained in the BOMEX fair-weather, trade-wind boundary layer. BoundaryLayer Meteorol. 23: 323-357.

Huang Q, Marsham JH, Parker D, Tian W, Weckwerth T. 2009. A comparison of roll and non-roll convection and the subsequent deepening moist convection: an LEM case study based on SCCMS data. Mon. Weather Rev. 137: 350-365.

Jacoby-Koaly S, Campistron B, Bernard S, Bénech B, Girard-Ardhuin F, Dessens J. 2002. Turbulent dissipation rate in the boundary layer via UHF wind profiler Doppler spectral width measurements. BoundaryLayer Meteorol. 103: 361-389.

Janicot S, Thorncroft CD, Ali A, Asencio N, Berry G, Bock O, Bourles B, Caniaux G, Chauvin F, Deme A, Kergoat L, Lafore JP, Lavaysse C, Lebel T, Marticorena B, Mounier F, Nedelec P, Redelsperger JL, Ravegnani F, Reeves CE, Roca R, De Rosnay P, Schlager H, Sultan B, Tomasini M, Ulanovsky A, and ACMAD forecasters team. 2008. Large-scale overview of the summer monsoon over West Africa during the AMMA field experiment in 2006. Ann. Geophys. 26: 2569-2595.

Kalapureddy MC, Lothon M, Campistron B, Lohou F, Saïd F. 2010. Wind profiler observations of the African Easterly Jet and its interactions with the boundary layer and Saharan heat low. Q. J. R. Meteorol. Soc. 136: 77-91.

Kalthoff N, Adler B, Barthlott CH, Corsmeier U, Mobbs S, Crewell S, Träumner K, Kottmeier CH, Wieser A, Smith V, Girolamo PDi. 2009. The impact of convergence zones on the initiation of deep convection: A case study from COPS. Atmos. Res. 93: 680-694.

Klüpfel V, Kalthoff N, Gantner L, Taylor CM. 2012. Convergence zones and their impact on the initiation of a mesoscale convective system in West Africa. Q. J. R. Meteorol. Soc. 138: 950-963. 
Knight CA, Miller JL. 1993. First radar echoes from cumulus clouds. Bull. Amer. Meteorol. Soc. 74: 179-188.

Koch SE, Ray CA. 1997. Mesoanalysis of summertime convergence zones in central and eastern North Carolina. Weather Forecasting 12: 56-77.

Kohler M, Kalthoff N, Kottmeier C. 2010. The impact of soil moisture modifications on CBL characteristics in West Africa: A case-study from the AMMA campaign. Q. J. R. Meteorol. Soc. 136: 442-455.

Koscielny AJ, Doviak RJ, Rabin R. 1982. Statistical considerations in the estimation of divergence from single-Doppler radar and application to prestorm boundary-layer observations. J. Appl. Meteorol. 21: $197-210$.

Kuettner JP. 1959. The band structure of the atmosphere. Tellus 2: 267-294.

Kuettner JP. 1971. Cloud bands in the Earth's atmosphere. Tellus 23. 404-425.

Le Barbé L, Lebel T. 1997. Rainfall climatology of the HAPEX-Sahel region during the years 1950-1990. J. Hydrol. 188-189: 43-73.

Lebel T, Parker DJ, Flamant C, Bourlès B, Marticorena B, Mougin E, Peugeot C, Diedhiou A, Haywood JM, Ngamini JB, Polcher J, Redelsperger JL, Thorncroft CD. 2009. The AMMA field campaigns: Multiscale and multidisciplinary observations in the West African region. Q. J. R. Meteorol. Soc. 136(S1): 8-33.

LeMone MA. 1973. The structure and dynamics of horizontal roll vortices in the planetary boundary layer. J. Atmos. Sci. 30: 1077-1091.

LeMone MA, Pennell WT. 1976. The relationship of trade wind cumulus distribution to subcloud layer fluxes and structure. Mon. Weather Rev. 104: 524-539.

Lima MA, Wilson W. 2008. Convection storm initiation in a moist tropical environment. Mon. Weather Rev. 136: 1847-1864.

Lothon M, Campistron B, Chong M, Couvreux F, Guichard F, Rio C, Williams E. 2011. Life cycle of a mesoscale circular gust front observed by a C-band Doppler radar in West Africa. Mon. Weather Rev. 139: 1370-1388.

Lothon M, Said F, Lohou F, Campistron B. 2008. Observation of the diurnal cycle in the low troposphere of West Africa. Mon. Weather Rev. 136: 3477-3500.

Lytinska Z, Parfiniewicz J, Pinkowski H. 1976. The prediction of air mass thunderstorms and hails. In Proceedings of WMO Symposium on the Interpretation of Broad-Scale NWP Products for Local Forecasting Purposes, Warsaw, Poland. World Meteorological Organization: Geneva, Switzerland. 128-130.

Mathon V, Laurent H. 2001. Life cycle of Sahelian mesoscale convective cloud systems. Q. J. R. Meteorol. Soc. 127: 377-406.

May PT. 1999. Thermodynamic and vertical velocity structure of two gust fronts observed with a wind profiler/RASS during MCTEX. Mon. Weather Rev. 127: 1796-1807.

Miller MA, Slingo A. 2007. The ARM mobile facility and its first international deployment: Measuring radiative flux divergence in West Africa. Bull. Am. Meteorol. Soc. 88: 1229-1244.

Parker DJ, Fink A, Janicot S, Ngamini JB, Douglas M, Afiesimama E, Agusti-Panareda A, Beljaars A, Dide F, Diedhiou A, Lebel T, Polcher J, Redelsperger JL, Thorncroft CD, Wilson A. 2005. The diurnal cycle of the West African monsoon circulation. Q. J. R. Meteorol. Soc. 131: 2839-2860.

Parker DJ, Fink A, Janicot S, Ngamini J-B, Douglas M, Afiesimama E, Agusti-Panareda A, Beljaars A, Dide F, Diedhiou A, Lebel T, Polcher J, Redelsperger J-L, Thorncroft CD, Wilson GA. 2008. The AMMA radiosonde program and its implications for the future of atmospheric monitoring over Africa. Bull. Am. Meteorol. Soc. 131: 1015-1027.

Purdom JFW. 1976. Some uses of high-resolution GOES imagery in the mesoscale forecasting of convection and its behavior. Mon. Weather Rev. 104: 1474-1483.

Ramier D, Boulain N, Cappelaere B, Timouk F, Rabanit M, Lloyd CR, Boubkraoui S, Metayer F, Descroix L, Wawrzyniak V. 2009. Towards an understanding of coupled physical and biological processes in the cultivated Sahel: 1. Energy and water. J. Hydrol. 375: 204-216.

Redelsperger JL, Thorncroft CD, Diedhiou A, Lebel T, Parker D, Polcher J. 2006. African monsoon multiplidisciplinary analysis: An international research project and field campaign. Bull. Am. Meteorol. Soc. 87: 1739-1746

Russell B, Williams ER, Gosset M, Cazenave F, Descroix L, Guy N, Lebel T, Ali A, Metayer F, Quantin G. 2010. Radar/rain-gauge comparisons on squall lines in Niamey, Niger for AMMA. Q. J. R. Meteorol. Soc. 136: $289-303$

Simpson JE, Britter RE. 1980. A laboratory model of an atmospheric mesofront. Q. J. R. Meteorol. Soc. 106: 485-500.

Sultan B, Janicot S. 2003. The West African monsoon dynamics. Part II: The preonset and onset of the summer monsoon. J. Climate 16: 3407-3427.

Taylor CM, Ellis RJ. 2006. Satellite detection of soil moisture impacts on convection at the mesoscale. Geophys. Res. Lett. 33: L03404, DOI: 10.1029/2005GL025252.

Taylor CM, Lebel T. 1998. Observational evidence of persistent convective-scale rainfall patterns. Mon. Weather Rev. 126: 1597-1607.

Taylor CM, Parker DJ, Burton RR, Thorncroft CD. 2003. Linking boundary-layer variability with convection : A case-study from JET2000. Q. J. R. Meteorol. Soc. 129: 2233-2253.

Taylor CM, Gounou A, Guichard F, Harris PP, Ellis RJ, Couvreux F, De Kauwe M. 2011. Frequency of Sahelian storm initiation enhanced over mesoscale soil-moisture patterns. Nature Geosci. 4: $430-433$.

Thorncroft CD. 1995. An idealized study of African easterly waves. III: More realistic basic states. Q. J. R. Meteorol. Soc. 121: 1589-1614.

Wai MMK, Smith EA, Beemoulin P, Culf AD, Dolman AJ, Lebel T. 1997. Variability in boundary layer structure during HAPEX-Sahel wet-dry season transition. J. Hydrol. 188-189: 965-997.

Wakimoto RM. 1982. The life cycle of thunderstorm gust fronts as viewed with Doppler radar and rawinsonde data. Mon. Weather Rev. 110: $1060-1082$

Waldteufel P, Corbin H. 1979. On the analysis of single-Doppler radar data. J. Appl. Meteorol. 18: 532-542.

Weckwerth TM. 1995. 'A study of horizontal convective rolls occuring within clear-air convective boundary layers'. PhD thesis, Dept. of Atmos. Sciences, University of California Los Angeles, CA

Weckwerth TM. 1999. An observational study of the evolution of horizontal convective rolls. Mon. Weather Rev. 127: 2160-2179.

Weckwerth TM. 2000. The effect of small-scale moisture variability on thunderstorm initiation. Mon. Weather Rev. 128: 4017-4030.

Weckwerth TM, Parsons DB. 2006. A review of convection initiation and motivation for IHOP_2002. Mon. Weather Rev. 134: 5-22.

Weckwerth TM, Wakimoto RM. 1992. The initiation and organization of convective cells atop a cold-air outflow boundary. Mon. Weather Rev. 120: 2169-2187.

Weckwerth TM, Wilson JW, Wakimoto RM, Crook NA. 1997. Horizontal convective rolls: Determining the environmental conditions supporting their existence and characteristics. Mon. Weather Rev. 125: 505-526.

Weckwerth TM, Parsons DB, Koch SE, Moore JA, LeMone MA, Demoz BB, Flamant C, Geerts B, Wang J, Feltz WF. 2004. An overview of the International $\mathrm{H}_{2} 0$ Project (IHOP_2002) and some preliminary highlights. Bull. Amer. Meteorol. Soc. 85: 253-277.

Wilde NP, Stull RB, Eloranta EW. 1985. The LCL zone and cumulus onset. J. Climatol. Appl. Meteorol. 24: 640-657.

Wilson JW, Foote GB, Crook NA, Fankhauser JC, Wade CG, Tuttle JD, Mueller CK. 1992. The role of boundary-layer convergence zones and horizontal rolls in the initiation of thunderstorms: A case study. Mon. Weather Rev. 120: 1785-1815.

Wilson JW, Mueller CK. 1993. Nowcasts of thunderstorm initiation evolution. Weather Forecasting 8: 113-131.

Wilson JW, Weckwerth T, Vivekanandan J, Wakimoto RM, Russel RW. 1994. Boundary-layer clear-air radar echoes: origin of echoes and accuracy of derived winds. J. Atmos. Oceanic Technol. 11: 1184-1209.

Wilson JW, Schreiber WE. 1986. Initiation of convective storms at radarobserved boundary-layer convergences lines. Mon. Weather Rev. 114 2516-2536.

Xin L, Reuter GW. 1998. VVP technique applied to an Alberta storm. J. Atmos. Oceanic Technol. 15: 587-592.

Zhang Y, Klein SA. 2010. Mechanisms affecting the transition from shallow to deep convection over land: Inferences from observations of the diurnal cycle collected at the ARM Southern Great Plains site. J. Atmos. Sci. 67: 2943-2959.

Zrnić DS, Lee JT. 1983. 'Investigation of the detectability and lifetime of gust fronts and other weather hazards to aviation'. FAA Report No. DOT/FAA/PM-83/33, 58pp. Available from NTIS, Springfield, VA 22151, NTIS No. AD-A141 552. 